\title{
Characterisation of old azulejos setting mortars: a contribution to the conservation of this type of coatings
}

Ana Leonor Damas, Department of Civil Engineering, NOVA University of Lisbon, 2829-516 Caparica, Portugal, a.damas@ campus.fct.unl.pt

Maria do Rosário Veiga, Buildings Department, National Laboratory for Civil Engineering, Lisbon, Portugal, rveiga@lnec.pt

Paulina Faria, CERIS and Department of Civil Engineering, NOVA University of Lisbon, 2829-516 Caparica, Portugal, paulina.faria@ fct.unl.pt

António Santos Silva, Materials Department, National Laboratory for Civil Engineering, Lisbon, Portugal, ssilva@lnec.pt

\begin{abstract}
One of the most typical Portuguese facades' coatings is the glazed tile (azulejo) wall coating. Azulejos are in Portuguese history for six centuries, being considered a historical heritage and a mark of Portuguese culture. The setting mortar used in the azulejos application plays an important role for the correct functioning of the entire coating system. Therefore, for correct conservation its study and well detailed characterisation are fundamental.
\end{abstract}

Within the scope of DB-HERITAGE project (Database of building materials with historical and heritage interest), a deep gathering of data from literature, concerning the characteristics of azulejos' setting mortars, from the 16th to the 20th centuries, was made. Adding to the existing data, a physical, mechanical, chemical and mineralogical characterisation of a set of azulejos' setting mortars, from the $16^{\text {th }}$ to the $19^{\text {th }}$ century, from Lisbon and Coimbra cities, was carried out. 
The results obtained in the experimental study were analysed and compared with the ones gathered from literature leading to establish useful conclusions for the prescription of future conservation interventions for this type of coating.

\section{Keywords:}

Azulejo; glazed tile; wall coating system; setting mortar; air lime; architectural heritage; characterisation; building conservation.

\section{INTRODUCTION}

In Portugal, the state of degradation of the built heritage is notorious and alarming, a condition that stands out especially when it is shown by the facades' coatings, whose main function is the protection of the walls. Several factors may be responsible for the degradation of a wall coating: excessive humidity namely from capillary rise, climatic exposure conditions, biological colonisation, pollution, lack of maintenance or even poorly planned conservation interventions that reveal to be incompatible with the characteristics of the building to be conserved.

One of the most typical types of wall coating in Portugal is the glazed tile coating system - named azulejos in portuguese (Figure 1), which is closely linked to the Portuguese history, thus constituting an important testimony of great cultural and touristic interest.

Azulejos coating is distinguished by its important aesthetic value and by its specific technique. Additionally, when well applied, its longevity is one of the most important and attractive characteristics, which increases the preference and the demand for this type of coating. Just like all the traditional wall coatings (external or internal), when subjected to the mentioned degradation factors, azulejos coatings also deteriorate. The 
most affected targets: the substrate (the masonry), the azulejos setting mortar and the azulejo itself.

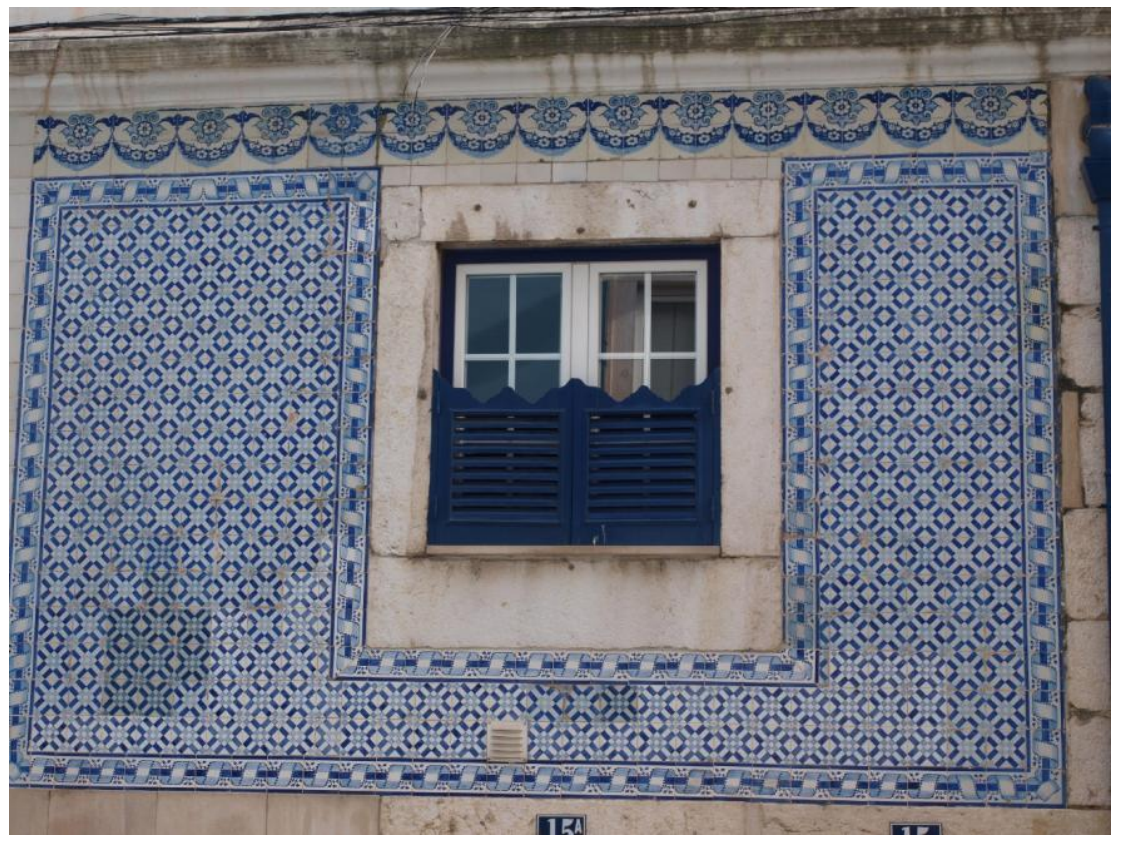

Figure 1 - Azulejos facade coating of a building in Calçada do Cardeal, Lisbon

In these old coatings, the mortar is the bond between the substrate and the azulejo itself; so its behaviour directly influences the system as a whole (Figure 2).

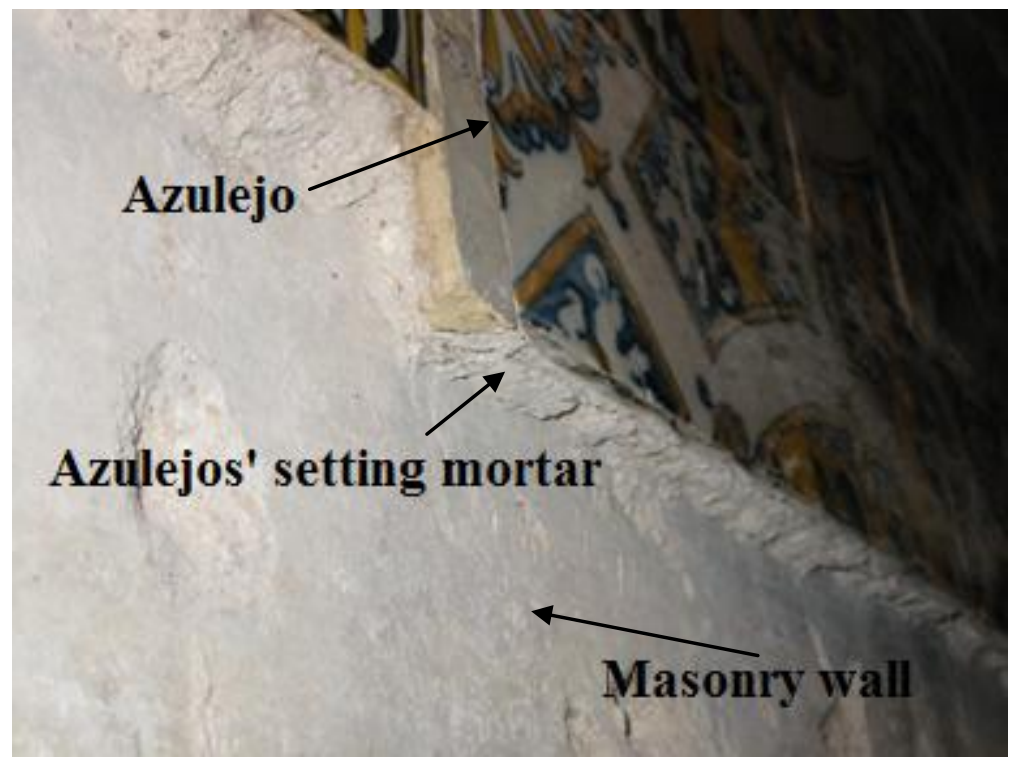

Figure 2 - Azulejos' internal coating system (Elvas Cathedral) 
When lack of adhesion occurs between the setting mortar and the masonry or the setting mortar and the azulejo, a conservation intervention is needed and a replacement setting mortar is used. The most compatible replacement mortars are those that have physical, mechanical, chemical and mineralogical characteristics similar to the original ones [1]. To assure compatibility, it is essential to determine in the first place the characteristics of the existing materials. Therefore, a well-fundamented matrix of knowledge can be developed to support future conservation and refurbishment interventions.

Considering the few works developed in the characterisation of old azulejos setting mortars, and given the increasing awareness for the preservation and conservation of this cultural and aesthetic heritage, the increase of knowledge regarding the characteristics of this type of mortars is extremely important and relevant.

The main objective of this article is the characterisation of old azulejos setting mortars in order to expand the knowledge matrix regarding the conservation and refurbishment of azulejos, on which still little information is available. To accomplish that objective, an experimental campaign was carried out on a set of 40 samples of old azulejos setting mortars provided by Museu Nacional do Azulejo (Portuguese Glazed Tile Museum, in Lisbon, Portugal), and the results obtained were correlated with those few results collected from literature and compared with other Portuguese coating mortars. It was also an objective of this study the evaluation of possible trends in azulejos setting mortars formulation through history, regions and types of building from which they come from.

\section{LITERATURE REVIEW ON AZULEJOS`SETTING MORTARS}

In several studies related to the characterisation of old mortars, the gap existing in the characterisation of azulejos setting mortars and the existing techniques for their application is recurrent and clear [2]. This gap may be due to the difficulty in the 
collection of significant samples, especially because they are under azulejo coating. During interventions in azulejo coatings, it is common to reject the mortar that is adhered to the rear face of the azulejo and this justifies the lack of samples.

In Portugal, Portland cement emerged in construction in the late $19^{\text {th }}$ century but was only consolidated in the market for masonry coatings in the second half of the $20^{\text {th }}$ century. Therefore, until then the mortars used in the settlement of azulejos were typically based on air lime [3].

In the absence of detailed information regarding the characterisation of azulejos setting mortars, most professionals that work directly in the conservation of old azulejo coatings base their techniques on the few references found in the literature and end up following the usual patterns, regardless of their suitability to the case being treated. A common example of the lack of experience and knowledge in poorly planned conservation interventions is the use of mortars with cementitious binders for the replacement of old azulejos. This type of mortars is completely inadequate for this kind of works, either chemically, because of their content of soluble salts, physically because of their low porosity and lack of water vapor permeability, or mechanically due to their high strength, stiffness and low deformability [4].

Fortunately, in a context where azulejo coatings heritage has become an increasingly important conservation and preservation target, the fundamental role that mortars play in the behaviour and durability of that type of coatings was recognised. Some investigations have emerged, which value the characterisation of this type of mortars, although briefly when compared to the importance given to the azulejos themselves [515].

A deep gathering of data, from the literature, concerning physical, mechanical, chemical and mineralogical main characteristics of some case studies of azulejos setting mortars 
is summarised in Table 1. The collected case studies are essentially from residential and religious buildings, from the Portuguese towns of Aveiro, Oporto, Santarém and Évora, from the $16^{\text {th }}$ to the $20^{\text {th }}$ centuries. It is verified that, in general, azulejos setting mortars present a calcitic lime binder, with rare exceptions in Oporto and Santarém, which show dolomitic lime binder. The aggregates are mainly siliceous, often containing clay minerals and rarely traces of ceramic fragments. Most of the samples considered in Table 1 are from building facades and so they are exterior mortars. But when they are compared with the few cases from interiors, no significant differences are found, leading to the assumption that no special distinction was made in the formulation and application of the two types. However, only further studies could prove this hypothesis. The mean binder: aggregate weight ratio obtained from the gathered case studies is approximately $1: 4$. The mean value of compressive strength is $1.67 \mathrm{~N} / \mathrm{mm}^{2}$ and the only value found of dynamic modulus of elasticity by ultrasounds is $1610 \mathrm{~N} / \mathrm{mm}^{2}$. Hydrated calcium silicates and silico-aluminates are present in some samples. Salts were generally found, namely gypsum (calcium sulphate) (mainly in samples taken from the interior) and halite (sodium chloride) (more often in the exterior walls), as well as arcanite (potassium sulphate). The presence of gypsum could be due to several factors: the migration of the sulphate ion from the indoor plasters of the building; intentional addition to improve the workability of the mortar or to decrease the hardening period; or the simple reaction of the atmospheric sulphates with the calcitic mortars [15]. On the other hand, the presence of halite is typical of environments close to sea. 
Table 1 - Portuguese case studies of azulejos' setting mortars from literature

\begin{tabular}{|c|c|c|c|c|c|}
\hline $\begin{array}{c}\text { Case study/Age/ Type } \\
\text { of building/ } \\
\text { Reference }\end{array}$ & Use & $\begin{array}{l}\text { Binder:Aggr. } \\
\text { (mass ratio) }\end{array}$ & $\begin{array}{c}\text { Minor } \\
\text { compounds }\end{array}$ & $\begin{array}{c}\mathrm{CS} \\
\left(\mathrm{N} / \mathrm{mm}^{2}\right)\end{array}$ & $\begin{array}{c}\mathrm{E}_{\mathrm{us}} \\
\left(\mathrm{N} / \mathrm{mm}^{2}\right)\end{array}$ \\
\hline $\begin{array}{c}\text { Misericórdia Church in } \\
\text { Aveiro } / 16^{\text {th }} / \text { Religious/ } \\
{[8]}\end{array}$ & Ext. & $\begin{array}{l}\text { Calcitic lime: } \\
\text { silic. agr (-) }\end{array}$ & Goethite & 0.48 & - \\
\hline $\begin{array}{c}\text { St. Dominic's } \\
\text { Monastery, Montemor- } \\
\text { o-Novo (Évora) } \\
/ 17^{\text {th }} / \text { Religious/ }[13,14]\end{array}$ & Int. & $\begin{array}{l}\text { Calcitic lime: } \\
\text { silic. agr. } \\
(1: 5)\end{array}$ & - & - & - \\
\hline $\begin{array}{l}\text { Building in Ovar } \\
\text { (Aveiro) } / 19^{\text {th }} / \\
\text { Residential/ }[6,9]\end{array}$ & Ext. & $\begin{array}{c}\text { Calcitic lime: } \\
\text { silic. agr. }+ \\
\text { clay and } \\
\text { traces of } \\
\text { ceramic } \\
\text { fragments } \\
(1: 2)\end{array}$ & $\begin{array}{c}\text { Hydrated } \\
\text { calcium } \\
\text { silicates and } \\
\text { silico- } \\
\text { aluminates, } \\
\text { portlandite, } \\
\text { halite, } \\
\text { anhydrite }\end{array}$ & 1.37 & 1610 \\
\hline $\begin{array}{c}\text { House of Vargos, } \\
\text { Torres Novas, } \\
\text { (Santarém) / } \\
19^{\text {th }}-20^{\text {th }} \\
\text { /Residential(?)/ }[13,14]\end{array}$ & Int. & $\begin{array}{l}\text { Calcitic and } \\
\text { dolomitic } \\
\text { lime (in } 1 \\
\text { sample): silic. } \\
\text { agr. (1:7) }\end{array}$ & $\begin{array}{l}\text { Goethite, } \\
\text { gypsum (?) } \\
\text { portlandite }\end{array}$ & - & - \\
\hline $\begin{array}{l}\text { Building in Ovar } \\
\text { (Aveiro) } / 19^{\text {th }}-20^{\text {th }} \\
\text { /Residential/ }[7,10]\end{array}$ & Ext. & $\begin{array}{l}\text { Calcitic lime: } \\
\text { silic. agr. }+ \\
\text { clay minerals } \\
(1: 3)\end{array}$ & $\begin{array}{c}\text { Portlandite } \\
\text { halite }\end{array}$ & 1.92 & - \\
\hline $\begin{array}{l}\text { Building in Oporto } \\
/ 20^{\text {th }} / \text { Residential/ [15] }\end{array}$ & $\begin{array}{l}\text { Ext. } \\
\text { and } \\
\text { Int. } \\
(1)\end{array}$ & $\begin{array}{l}\text { Calcitic and } \\
\text { dolomitic } \\
\text { lime: silic. } \\
\text { agr. (1:6) }\end{array}$ & $\begin{array}{l}\text { Arcanite, } \\
\text { gypsum, } \\
\text { halite }\end{array}$ & - & - \\
\hline $\begin{array}{c}\text { Major Pessoa's House } \\
\text { (Aveiro) } / 20^{\text {th }} / \\
\text { Residential/ }[5,8]\end{array}$ & Int. & $\begin{array}{l}\text { Calcitic lime: } \\
\text { silic. agr. (-) }\end{array}$ & $\begin{array}{l}\text { Halite, } \\
\text { goethite, } \\
\text { anhydrite }\end{array}$ & 1.82 & - \\
\hline
\end{tabular}

Used notation: $\mathrm{CS}$ - compressive strength; $\mathrm{E}_{\mathrm{us}}-$ dynamic modulus of elasticity by ultrasounds; (-) - unidentified; (?) - uncertainty. 


\section{SAMPLES AND METHODS}

\subsection{Samples}

The experimental program developed in the present study involved 40 samples of old azulejos setting mortars, provided by the Portuguese Tile Museum. Each sample was constituted by one or more mortar specimens from the same azulejo/panel, removed with the aid of a hammer and chisel during the collection and restoration interventions carried out by the museum.

Given the diversity of the existing samples, it was necessary to inventory them and then categorise them for different tests, according to their dimensions and consistency. After this initial phase, the samples were physico-mechanically and chemical-mineralogically characterised.

The samples analysed belong to the $16^{\text {th }}$ to the $19^{\text {th }}$ century, and are from the regions of Lisbon (19 samples) and Coimbra (21 samples) and most of them belonged to residential/palatial and religious buildings. The designation attributed to each sample is directly related to the mortars provenance. In some cases, only the provenance city was available, not the exact location, origin or type of building. In most cases it was possible to know the century of the buildings' construction.

Table 2 presents the initial identification of the main samples under analysis (8), i.e. the ones that will be further used in mechanical, physical, chemical and mineralogical tests campaign. Table 3 presents the identification of the other 32 samples of smaller dimensions (small fragments and powders) that will be further used only in chemical and mineralogical tests. 
Table 2 - Identification and main characteristics of the azulejos setting mortars that were able to be fully characterised

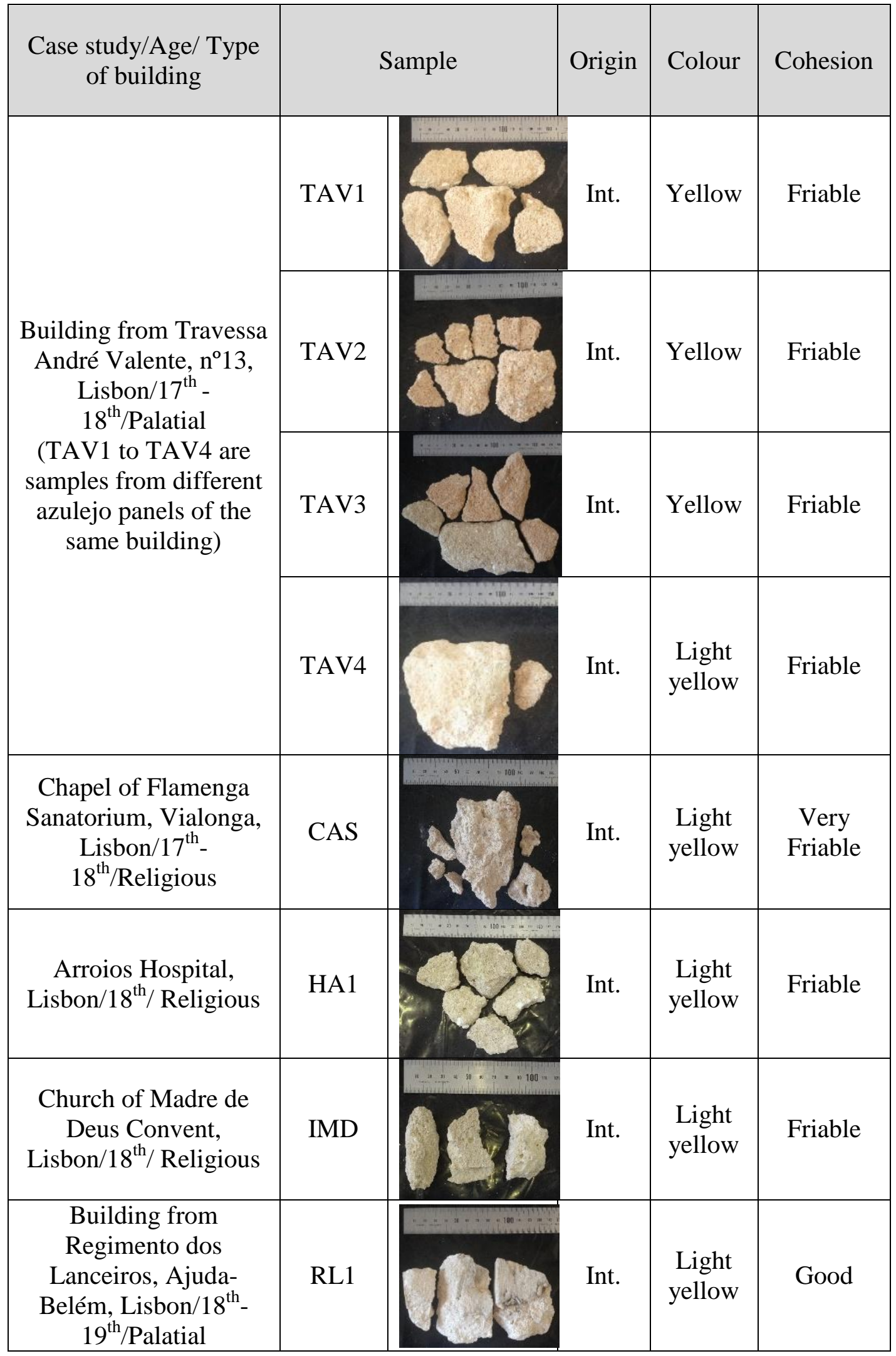


Table 3 - Identification and main characteristics of the azulejo setting mortar samples of smaller dimensions

\begin{tabular}{|c|c|c|c|}
\hline $\begin{array}{l}\text { Case study/Age/ Type of } \\
\text { building }\end{array}$ & Sample & Origin & Dimensions \\
\hline \multirow{4}{*}{$\begin{array}{l}\text { Archaeological excavations, } \\
\text { Lisbon } / 16^{\text {th }} / ?\end{array}$} & ARQ1 & \multirow{4}{*}{ Unknown } & powder \\
\hline & ARQ2 & & small fragments \\
\hline & ARQ3 & & small fragments \\
\hline & ARQ4 & & small fragments \\
\hline \multirow{2}{*}{$\begin{array}{l}\text { Hispano-Moorish } \\
\text { azulejos } / 17^{\text {th }} / ?\end{array}$} & HM1 & \multirow{2}{*}{ Unknown } & \multirow{2}{*}{ small fragments } \\
\hline & HM2 & & \\
\hline $\begin{array}{l}\text { Panel from } \\
\text { Lisbon } / 17^{\text {th }} / ?\end{array}$ & PL & Unknown & powder \\
\hline \multirow{2}{*}{$\begin{array}{l}\text { Arroios Hospital, Lisbon } / 18^{\text {th }} / \\
\text { Religious }\end{array}$} & HA2 & Interior & powder \\
\hline & HA3 & Interior & small fragments \\
\hline $\begin{array}{l}\text { "Monte Sião" Panel, } \\
\text { Coimbra/ } 18 \text { th } / ?\end{array}$ & MMC1 & \multirow{10}{*}{ Unknown } & small fragments \\
\hline Cod. A Panel, Coimbra/ $18 \mathrm{t}^{\mathrm{h}} / ?$ & MMC2 & & small fragments \\
\hline $\begin{array}{l}\text { Panel } 4 \text { landscape, } \\
\text { Coimbra/ } 18^{\text {th }} / ?\end{array}$ & MMC3 & & small fragments \\
\hline \multirow{5}{*}{$\begin{array}{l}\text { "Apocalipse" Panel, } \\
\text { Coimbra/18th/? }\end{array}$} & MMC4 & & powder \\
\hline & MMC5 & & small fragments \\
\hline & MMC6 & & powder \\
\hline & MMC7 & & small fragments \\
\hline & MMC8 & & powder \\
\hline Cod. 3 Panel, Coimbra/ $18^{\text {th }} / ?$ & MMC9 & & small fragments \\
\hline Panel 3, Coimbra/18 $/ 8^{\text {th }} / ?$ & MMC10 & & powder \\
\hline $\begin{array}{l}\text { Building from Regimento dos } \\
\text { Lanceiros, Ajuda-Belém, } \\
\text { Lisbon } / 18^{\text {th }}-19^{\text {th }} / \text { Palatial }\end{array}$ & RL2 & Interior & small fragments \\
\hline $\begin{array}{l}\text { Decorative ceramic plaque } \\
\text { manufactured in Fábrica } \\
\text { Roseira, Lisbon } / 19^{\text {th }} / \\
\text { Residential }\end{array}$ & FR & Interior & small fragments \\
\hline \multirow{3}{*}{$\begin{array}{l}\text { "Triunfo da Religião" Panel, } \\
\text { Coimbra/?/? }\end{array}$} & MMC11 & \multirow{11}{*}{ Unknown } & small fragments \\
\hline & MMC12 & & small fragments \\
\hline & MMC13 & & small fragments \\
\hline \multirow{2}{*}{ Cod. F panel, Coimbra/?/? } & MMC14 & & small fragments \\
\hline & MMC15 & & small fragments \\
\hline \multirow{2}{*}{$\begin{array}{c}\text { "O homem da gaita de foles" } \\
\text { panel, Coimbra/?/? }\end{array}$} & MMC16 & & small fragments \\
\hline & MMC17 & & powder \\
\hline \multirow{2}{*}{ Cod. 13 panel, Coimbra/?/? } & MMC18 & & powder \\
\hline & MMC19 & & small fragments \\
\hline Panel, Coimbra/?/? & MMC20 & & powder \\
\hline $\begin{array}{l}\text { "Simbologia Mariana" Panel, } \\
\text { Coimbra/?/? }\end{array}$ & MMC21 & & small fragments \\
\hline
\end{tabular}


Most samples studied, at least those with information about their origin, come from azulejos applied indoors. All samples present a yellowish colour, some lighter than others and they are friable, as frequently happens with ancient air lime mortars (the sample CAS was extremely friable) with the exception of sample RL1, which was very compact.

\subsection{Physico-mechanical characterisation tests}

As shown in Table 2, the old azulejos setting mortar samples are very irregular. Due to size limitations, only the samples with the largest (approximately 70x50x20 $\mathrm{mm}^{3}$ ) and most compact fragments were mechanically tested (compressive strength test) and only one could be tested for dynamic modulus of elasticity. Capillary absorption was performed in intermediate sized samples fragments (approximately 60x50x20 $\mathrm{mm}^{3}$ ) and open porosity was performed in smaller fragments of samples (approximately 50x30x10

$\mathrm{mm}^{3}$ ). The samples composed of only very small fragments, or even of powder, could only be submitted to chemical and mineralogical characterisation tests.

\subsubsection{Compressive strength}

The compressive strength (CS) is one of the most important characteristics to be evaluated in ancient air lime coating mortars because it leads to establish which limits of strength must be respected to ensure compatibility between old mortars and the replacement ones.

Given the irregularity and friability of the samples, it was impossible to follow exactly the standardized test method for mortars, as described on EN 1015-11 [16]. Therefore, for the compressive strength study of the setting mortars, a method developed under earlier research projects of ancient coating mortars and previously validated $[17,18]$ was used. It consisted on the application of a shaping mortar of cement and sand with a 
volumetric proportion of 1:3 (harder than the one under testing) to regularise the faces of the samples that would be in contact with the plates of the test device, in order to get a good distribution of the applied force (Figure 3).

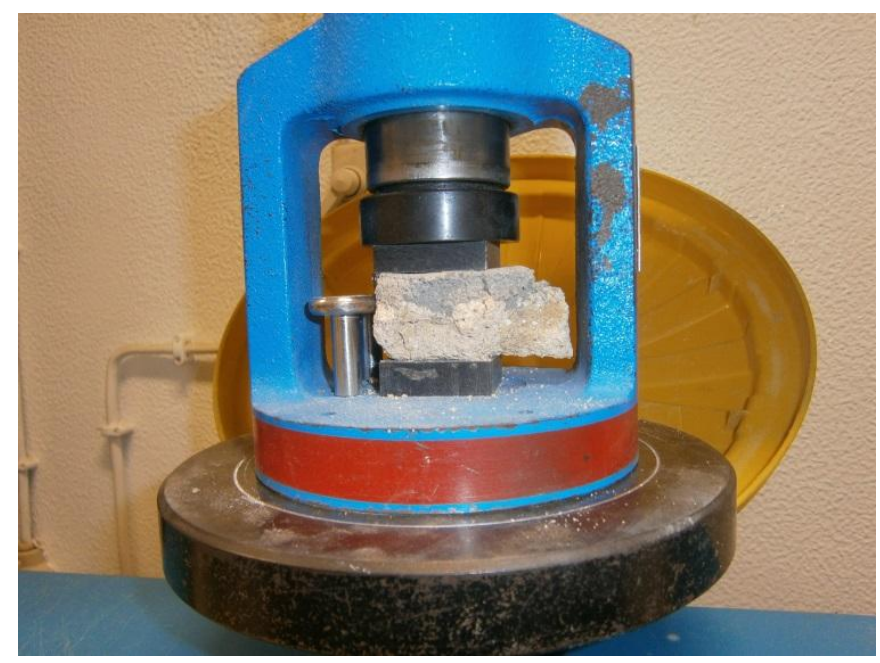

Figure 3 - General view of the applied compressive strength test

The contact area of the tops of the specimens did not follow specific dimensions since the main objective was to regularise the surface with the thinnest possible layer of cement mortar, so it would not compromise the results. This test was carried out in five specimens, from four different buildings, and the device used for the test was an ETI HM-S equipment with a $2 \mathrm{kN}$ load cell.

\subsubsection{Dynamic modulus of elasticity by ultrasounds}

Dynamic modulus of elasticity $\left(\mathrm{E}_{\mathrm{us}}\right)$ is another mechanical property important to take into account in the characterisation of ancient air lime coating mortars because, in conservation interventions, that value should be taken as a basis and respected in order to assure stiffness compatibility between the old and the substitution mortars.

However, it was only possible to perform this test in sample TAV4 because, for accuracy, this test needs a large dimension in at least one direction and TAV4 was the only sample that included a specimen that respected this condition, with approximately 
110x120x20 $\mathrm{mm}^{3}$ (Figure 4). The test was carried out with a Steinkamp Ultrasonic Tester BP-7 and based on EN 14146 [19]. The Poisson coefficient admitted for the determination of the $\mathrm{E}_{\mathrm{us}}$ was 0.2 .
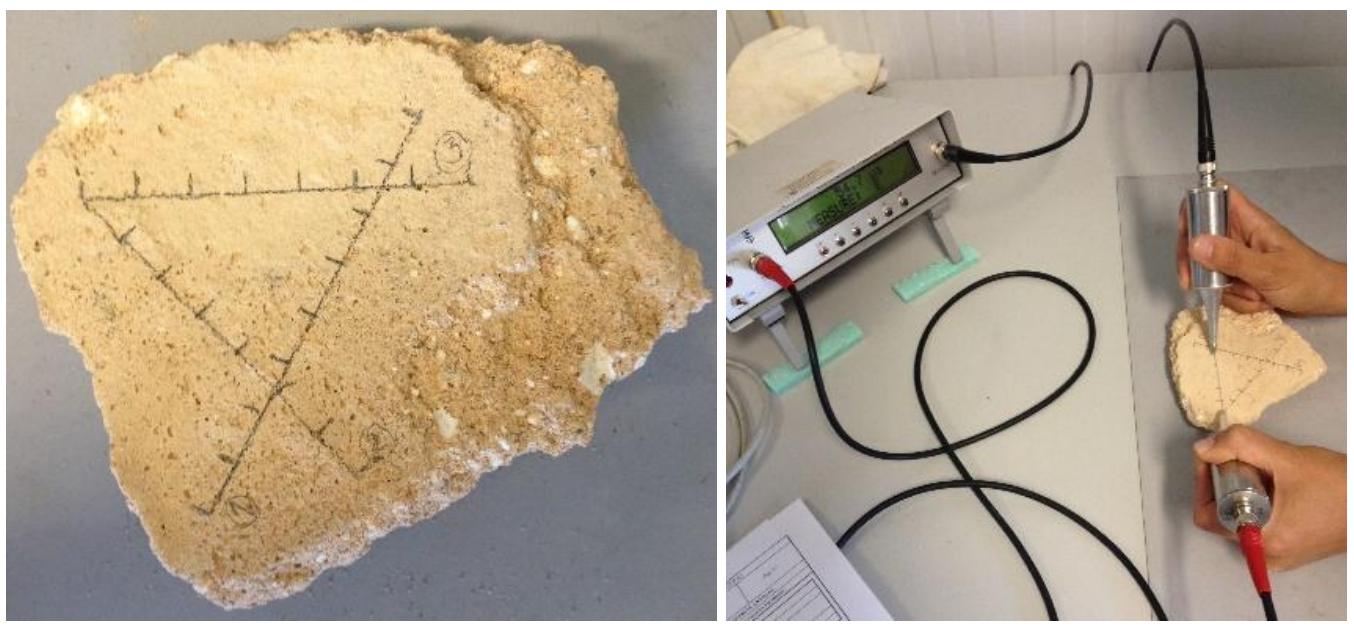

Figure 4 - Images showing a sample marked for the application of dynamic modulus of elasticity test (left), and the test being performed (right)

\subsubsection{Capillary absorption and drying of the absorbed water}

Some of the most critical azulejos coatings anomalies occur due to the water absorption and drying capacity of azulejos setting mortars. To attain compatibility between the old mortar and the substitution one it is important to assure that the wall after intervention presents a hygric behaviour similar to the wall with its original materials. Therefore, the study of these properties is extremely important to guarantee that in future conservation actions the previous hygrometric characteristics can be assured or only slightly modified (by slightly lowering the capillary absorption coefficient without significantly reducing the drying capacity).

This test was carried out in 12 specimens. The irregular shape and the friability of the mortars made it impossible to exactly apply the standard test methods described in EN 15801 [20]. For that reason, an adapted method was used which was developed and validated for friable and irregular samples [21]. It consists of allowing the absorption of 
water through contact with a saturated geotextile sheet in contact with water (Figure 5) and it was performed in a conditioned room under $\mathrm{T}=20 \pm 2{ }^{\circ} \mathrm{C}$ and a $\mathrm{HR}=65 \pm 5 \%$.

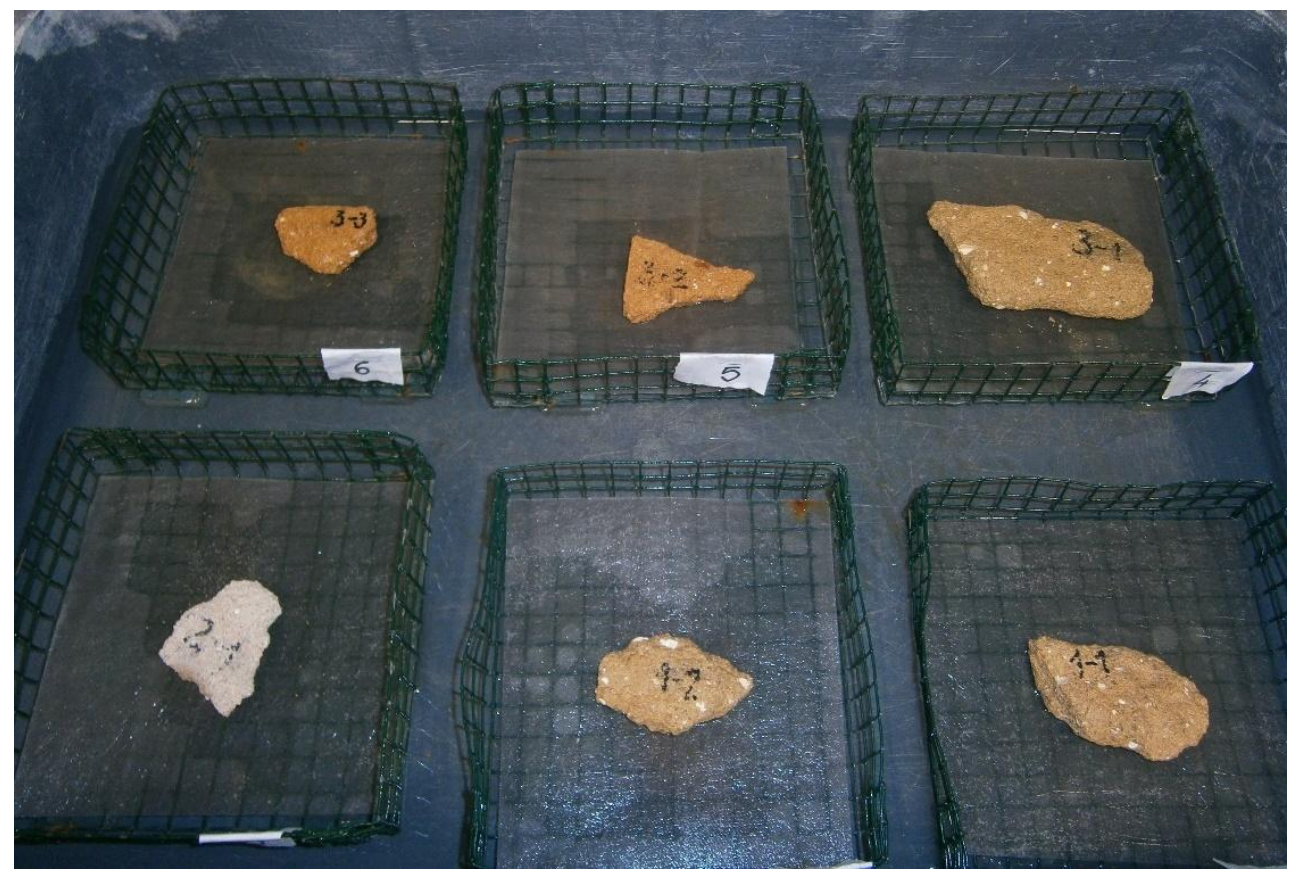

Figure 5 - Image showing the samples during the capillary absorption test

The azulejos setting mortar face in contact with the wet geotextile sheet was the one that had been in contact with the rear face of the azulejo before its removal. The weight of the sample was measured, with a precision balance of $0.01 \mathrm{~g}$, every minute in the first 10 minutes, then every 5 minutes until 40 minutes, then at 60, 90, 180, 300, 480 and 1440 minutes, and thereafter each $24 \mathrm{~h}$ until the saturation of the sample. From this test it was possible to determine the capillary absorption coefficient by contact (Ccc in $\left.\mathrm{kg} /\left(\mathrm{m}^{2} \cdot \mathrm{min}^{1 / 2}\right)\right)$ of each sample. This parameter expresses the initial water absorption rate of a specimen and is determined by the slope of the initial phase of the curve, based on a linear regression, as specified by EN 15801.

The drying process consisted of placing each specimen on two glass strips (Figure 6) and registering their weight at 30,60, 90, 270, 450 and 1440 minutes and thereafter each $24 \mathrm{~h}$ until constant weight. The drying rates corresponding to the first drying phase $\left(D_{1}\right.$ in $\left.\mathrm{kg} /\left(\mathrm{m}^{2} \cdot \mathrm{min}\right)\right)$ and to the second drying phase $\left(\mathrm{D}_{2}\right.$ in $\left.\mathrm{kg} /\left(\mathrm{m}^{2} \cdot \mathrm{min}^{1 / 2}\right)\right)$ were 
determined according to EN 16322 [22]. The drying area was considered as the sum of the upper and lower faces. In fact, the contact area of the samples with the glass strips was very small in comparison with the free area because of irregularities of the contact surface of the samples, and was therefore despised.

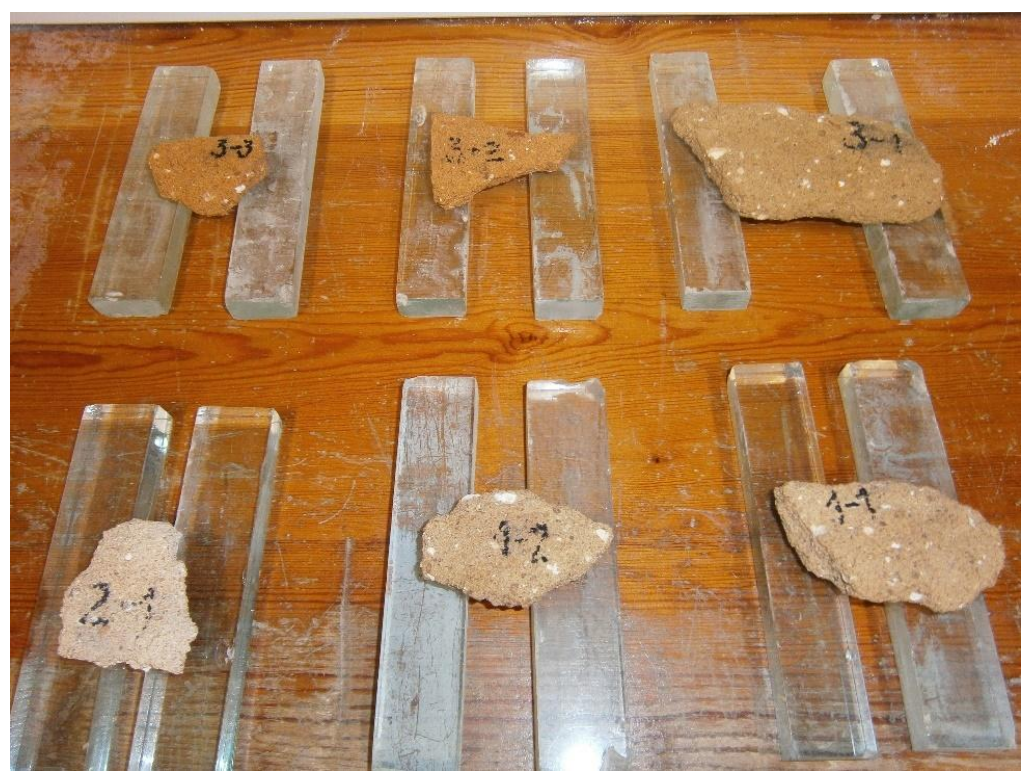

Figure 6 - Mortar samples during the drying process

\subsubsection{Open porosity}

The open porosity (Po) of a mortar consists of a continuous network of pores that allows liquid and gas circulation inside the material.

Open porosity test was performed in 14 mortar specimens based on EN 1936 [23] (Figure 7) with vacuum and hydrostatic weighting. The percentage of open pores was measured as well as the mortars' bulk density $\left(\mathrm{kg} / \mathrm{m}^{3}\right)$. 


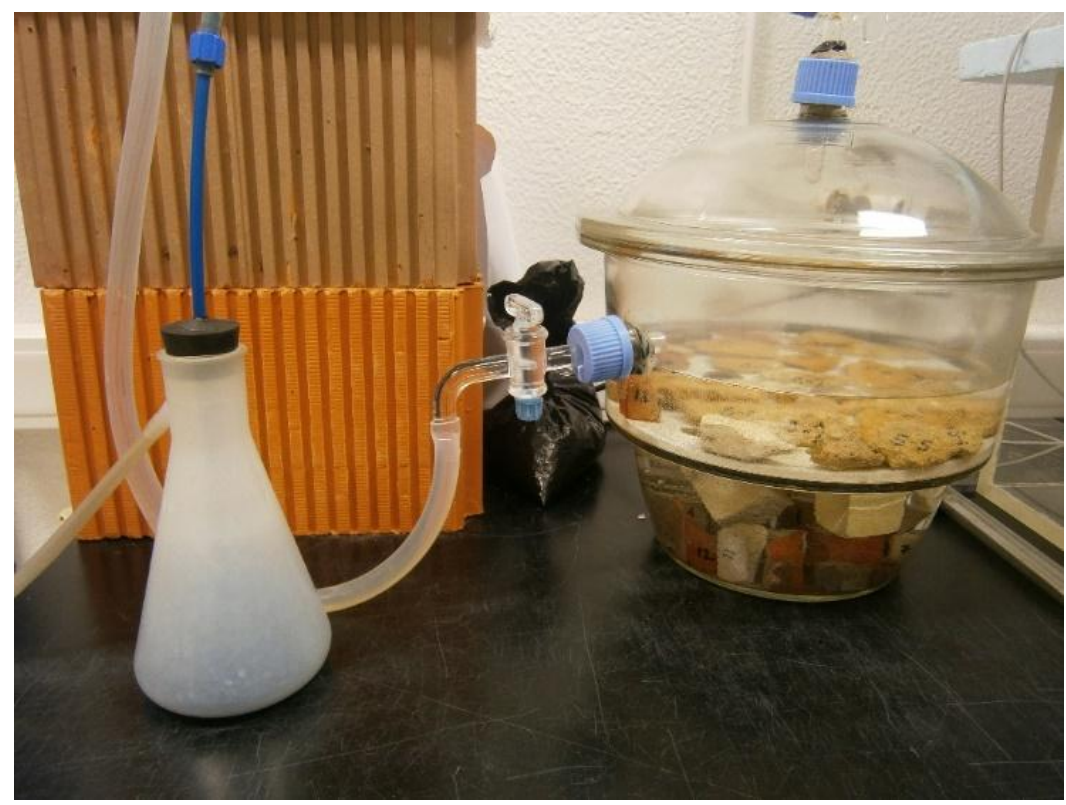

Figure 7 - Apparatus used for the open porosity test

\subsection{Chemical-mineralogical characterisation tests}

All the 40 samples were used in the mineralogical tests but, due to the small amount of sample available, only 8 were submitted to chemical analysis. It should be emphasized that specimens different from the ones used in the physical-mechanical tests were employed in order to avoid the influence of these test procedures in the mineralogical and chemical results.

X-ray diffraction (XRD) and thermogravimetric analysis (TG) were the methods used for mineralogical samples characterisation. To obtain the aggregate content, samples were chemically digested in hydrochloric acid. In some samples the aggregate nature was also confirmed using the scanning electron microscopy with X-ray microanalysis (SEM/EDS).

Whenever possible, sample specimens for XRD analysis were prepared in two fractions: the overall fraction corresponds to the mortar as collected and is obtained by disaggregating a complete mortar sample (including aggregates) and grinding it to pass in a 106- $\mu \mathrm{m}$ sieve; the fine fraction, which has a higher binder concentration, is 
obtained from disaggregating a mortar sample, removing the visible aggregates and grinding the particles of the mortar matrix to obtain material passing the $106-\mu \mathrm{m}$ sieve [24].

\subsubsection{X-Ray Diffraction Analysis}

The XRD analysis is a reliable and largely used technique when it comes to ancient mortars characterisation. This technique provides information about the minerals present in a sample; however, it is not that simple to quantify the proportions of the different minerals identified. For that reason, it is normally complemented by other techniques, such as TG analysis.

XRD was carried out with a Philips PW1830 diffractometer with $35 \mathrm{kV}$ and 45mA Co $\mathrm{K} \alpha$ radiation, and a speed of $0.05 \%$ from 3 to $742 \theta$.

\subsubsection{Thermogravimetric analysis}

The overall fraction of each sample was also used for thermal analysis (TG) performed in a SETARAM TGA-DTA analyser model 92, under argon atmosphere, with heating rate of $10{ }^{\circ} \mathrm{C} / \mathrm{min}$, from room temperature to $1000^{\circ} \mathrm{C}$.

\subsubsection{Chemical analysis - insoluble residue determination}

The binder:aggregate ratio was determined using the insoluble residue value obtained from a warm diluted (1:3) hydrochloric acid attack, that was employed to separate the binder from the siliceous aggregates. This analysis was done in TAV1, TAV2, TAV3, TAV4, HA1, CAS, RL1 and IMD samples.

\subsubsection{Scanning electron microscopy with $X$-ray microanalysis}


SEM/EDS analysis was performed in samples TAV2, TAV4, HA1 and IMD to confirm the absence of calcareous aggregate grains, otherwise it would compromise the binder:aggregate ratios previously determined.

Polished surfaces of the mortars were prepared by vacuum impregnation with an epoxy resin, which are lapped and polished with appropriate abrasives and then covered with a thin coat of gold to enable good surface electrical conductivity. Once prepared, the observations were performed with a SEM JEOL JSM-600 coupled with an Oxford Inca X-Sight energy dispersive X-ray spectrometer.

\section{RESULTS AND DISCUSSION}

\subsection{Chemical-mineralogical characterisation}

The mean results obtained from the chemical-mineralogical characterisation are summarised in Table 4. The samples are presented in chronological order, whenever the age of the building and/or the provenance of the azulejos are known.

Table 4 - Results of chemical and mineralogical characterisation of azulejos setting mortars

\begin{tabular}{|c|c|c|c|c|}
\hline $\begin{array}{l}\text { Case study/Age/ } \\
\text { Type of building }\end{array}$ & Sample & Composition & $\begin{array}{c}\mathrm{B}: \mathrm{Ag} \\
(\mathrm{wt})\end{array}$ & Other compounds \\
\hline \multirow{4}{*}{$\begin{array}{l}\text { Archaeological } \\
\text { excavations, } \\
\text { Lisbon } / 16^{\text {th }} / ?\end{array}$} & ARQ1 & \multirow{4}{*}{$\begin{array}{l}\text { Calcitic air lime: } \\
\text { silic. aggr. + clay } \\
\text { minerals }\end{array}$} & $1: 7$ & \multirow{4}{*}{ - } \\
\hline & ARQ2 & & $1: 2$ & \\
\hline & ARQ3 & & $1: 3$ & \\
\hline & ARQ4 & & $1: 3$ & \\
\hline \multirow{2}{*}{$\begin{array}{l}\text { Hispano-Moorish } \\
\text { azulejos } / 17^{\text {th }} / ?\end{array}$} & HM1 & \multirow{2}{*}{$\begin{array}{l}\text { Calcitic air lime: } \\
\text { silic. agr. + clay } \\
\text { minerals }\end{array}$} & $1: 2$ & \multirow{2}{*}{$\begin{array}{l}\text { Hydrated calcium } \\
\text { aluminate }\end{array}$} \\
\hline & HM2 & & $1: 2$ & \\
\hline $\begin{array}{c}\text { Panel from } \\
\text { Lisbon } / 17^{\text {th }} / ?\end{array}$ & PL & $\begin{array}{l}\text { Calcitic air lime: } \\
\text { silic. aggr. }\end{array}$ & $1: 1$ & Gypsum? \\
\hline \multirow{4}{*}{$\begin{array}{l}\text { Building in Travessa } \\
\text { André Valente, } \mathrm{n}^{\mathrm{o}} 13 \text {, } \\
\text { Lisbon } / 17^{\text {th }}- \\
18^{\text {th }} / \text { Palatial }\end{array}$} & TAV1 & \multirow{4}{*}{$\begin{array}{l}\text { Calcitic air lime: } \\
\text { silic. aggr. + clay } \\
\text { minerals }\end{array}$} & $1: 11$ & Gypsum \\
\hline & TAV2 & & $1: 7$ & - \\
\hline & TAV3 & & $1: 11$ & $\begin{array}{l}\text { Hydrocalumite, } \\
\text { gypsum }\end{array}$ \\
\hline & TAV4 & & $1: 5$ & \\
\hline
\end{tabular}




\begin{tabular}{|c|c|c|c|c|}
\hline $\begin{array}{c}\text { Chapel of Flamenga } \\
\text { Sanatorium, } \\
\text { Vialonga, } \\
\text { Lisbon } / 17^{\text {th }}- \\
18^{\text {th }} / \text { Religious }\end{array}$ & CAS & $\begin{array}{l}\text { Calcitic air lime: } \\
\text { silic. aggr. }+ \\
\text { traces of clay } \\
\text { minerals }\end{array}$ & $1: 3$ & - \\
\hline \multirow{3}{*}{$\begin{array}{l}\text { Arroios Hospital, } \\
\text { Lisbon } / 18^{\text {th }} / \\
\text { Religious }\end{array}$} & HA1 & \multirow{3}{*}{$\begin{array}{l}\text { Calcitic air lime: } \\
\text { silic. aggr. + clay } \\
\text { minerals (HA2, } \\
\text { HA3) }\end{array}$} & $1: 3$ & \multirow{3}{*}{-} \\
\hline & HA2 & & $1: 4$ & \\
\hline & HA3 & & $1: 3$ & \\
\hline $\begin{array}{l}\text { Church of Madre de } \\
\text { Deus Convent, } \\
\text { Lisbon } / 18^{\text {th }} / \\
\text { Religious } \\
\end{array}$ & IMD & $\begin{array}{l}\text { Calcitic air lime: } \\
\text { silic. aggr. }\end{array}$ & $1: 3$ & - \\
\hline $\begin{array}{l}\text { "Monte Sião" Panel, } \\
\text { Coimbra } 18^{\text {th }} / ?\end{array}$ & MMC1 & $\begin{array}{l}\text { Dolomitic air } \\
\text { lime: silic. aggr. }+ \\
\text { clay minerals }\end{array}$ & $1: 4$ & $\begin{array}{l}\text { Hydrated calcium } \\
\text { aluminate }\end{array}$ \\
\hline $\begin{array}{l}\text { Cod. A Panel, } \\
\text { Coimbra/ } 18 \mathrm{t}^{\mathrm{h}} / ?\end{array}$ & MMC2 & $\begin{array}{l}\text { Dolomitic air } \\
\text { lime: silic. aggr. }+ \\
\text { a lot of clay } \\
\text { minerals }\end{array}$ & $1: 6$ & $\begin{array}{l}\text { Hydrated calcium } \\
\text { aluminate }\end{array}$ \\
\hline $\begin{array}{l}\text { Panel } 4 \text { landscape, } \\
\text { Coimbra } / 18^{\text {th }} / ?\end{array}$ & MMC3 & $\begin{array}{l}\text { Dolomitic air } \\
\text { lime: silic. aggr. }+ \\
\text { clay minerals }\end{array}$ & $1: 3$ & $\begin{array}{l}\text { Hydrated calcium } \\
\text { aluminate }\end{array}$ \\
\hline \multirow{5}{*}{$\begin{array}{l}\text { "Apocalipse" Panel, } \\
\text { Coimbra/ } 18^{\text {th }} / ?\end{array}$} & MMC4 & \multirow{5}{*}{$\begin{array}{l}\text { Dolomitic air } \\
\text { lime: silic. aggr. + } \\
\text { clay minerals (big } \\
\text { amount in } \\
\text { MMC5) }\end{array}$} & $1: 3$ & \multirow{5}{*}{$\begin{array}{l}\text { Hydrated calcium } \\
\text { aluminate }\end{array}$} \\
\hline & MMC5 & & $\begin{array}{l}1: 4- \\
1: 5\end{array}$ & \\
\hline & MMC6 & & $1: 5$ & \\
\hline & MMC7 & & $1: 6$ & \\
\hline & MMC8 & & $1: 4$ & \\
\hline $\begin{array}{l}\text { Cod. } 3 \text { Panel, } \\
\text { Coimbra/18th/? }\end{array}$ & MMC9 & $\begin{array}{c}\text { Dolomitic air } \\
\text { lime: silic. aggr. }+ \\
\text { clay }\end{array}$ & $1: 4$ & $\begin{array}{l}\text { Hydrated calcium } \\
\text { aluminate }\end{array}$ \\
\hline $\begin{array}{c}\text { Panel 3, } \\
\text { Coimbra/18th/? }\end{array}$ & MMC10 & $\begin{array}{c}\text { Dolomitic air } \\
\text { lime: silic. aggr }\end{array}$ & $1: 5$ & $\begin{array}{l}\text { Hyd. calcium } \\
\text { aluminate }\end{array}$ \\
\hline \multirow{2}{*}{$\begin{array}{c}\text { Building from } \\
\text { Regimento dos } \\
\text { Lanceiros, Ajuda- } \\
\text { Belém, Lisbon/18th- } \\
\text { 19th/Palatial }\end{array}$} & RL1 & \multirow{2}{*}{$\begin{array}{l}\text { Calcitic air lime: } \\
\text { silic. aggr. }\end{array}$} & $1: 2$ & - \\
\hline & RL2 & & $1: 2$ & - \\
\hline $\begin{array}{l}\text { Decorative ceramic } \\
\text { plaque manufactured } \\
\text { in Fábrica Roseira, } \\
\text { Lisbon/19th/ } \\
\text { Residential }\end{array}$ & FR & $\begin{array}{l}\text { Calcitic air lime: } \\
\text { silic. aggr. }\end{array}$ & $1: 6$ & - \\
\hline \multirow{3}{*}{$\begin{array}{c}\text { "Triunfo da } \\
\text { Religião" Panel, } \\
\text { Coimbra/?/? }\end{array}$} & MMC11 & $\begin{array}{c}\text { Dolomitic air } \\
\text { lime: silic. aggr. }+\end{array}$ & $1: 3$ & \multirow{3}{*}{$\begin{array}{l}\text { Hyd. calcium } \\
\text { aluminate }\end{array}$} \\
\hline & MMC12 & $\begin{array}{l}\text { clay minerals (big } \\
\text { amount in }\end{array}$ & $1: 3$ & \\
\hline & MMC13 & $\begin{array}{l}\text { MMC11 and } \\
\text { MMC12) }\end{array}$ & $1: 3$ & \\
\hline
\end{tabular}




\begin{tabular}{|c|c|c|c|c|}
\hline \multirow{2}{*}{$\begin{array}{l}\text { Cod. F panel, } \\
\text { Coimbra/?/? }\end{array}$} & MMC14 & \multirow{2}{*}{$\begin{array}{c}\text { Dolomitic air } \\
\text { lime: silic. aggr. + } \\
\text { clay minerals }\end{array}$} & $1: 2$ & \multirow{2}{*}{$\begin{array}{l}\text { Hyd. calcium } \\
\text { aluminate }\end{array}$} \\
\hline & MMC15 & & $1: 3$ & \\
\hline \multirow{2}{*}{$\begin{array}{c}\text { "O homem da gaita } \\
\text { de foles" panel, } \\
\text { Coimbra/?/? }\end{array}$} & MMC16 & \multirow{2}{*}{$\begin{array}{l}\text { Dolomitic air } \\
\text { lime: silic. aggr. + } \\
\text { clay minerals }\end{array}$} & $1: 4-$ & \multirow{2}{*}{$\begin{array}{l}\text { Hyd. calcium } \\
\text { aluminate }\end{array}$} \\
\hline & MMC17 & & $1: 2$ & \\
\hline \multirow{2}{*}{$\begin{array}{c}\text { Cod. } 13 \text { panel, } \\
\text { Coimbra/?/? }\end{array}$} & MMC18 & \multirow{2}{*}{$\begin{array}{l}\text { Dolomitic air } \\
\text { lime: silic. aggr. + } \\
\text { clay minerals }\end{array}$} & $\begin{array}{l}1: 3- \\
1 \cdot 4\end{array}$ & \multirow{2}{*}{$\begin{array}{l}\text { Hyd. calcium } \\
\text { aluminate }\end{array}$} \\
\hline & MMC19 & & $1: 3$ & \\
\hline Panel, Coimbra/?/? & MMC20 & $\begin{array}{l}\text { Dolomitic air } \\
\text { lime: silic. aggr. + } \\
\text { clay minerals }\end{array}$ & $1: 6$ & $\begin{array}{l}\text { Hyd. calcium } \\
\text { aluminate }\end{array}$ \\
\hline $\begin{array}{c}\text { "Simbologia } \\
\text { Mariana" Panel, } \\
\text { Coimbra/?/? }\end{array}$ & MMC21 & $\begin{array}{l}\text { Dolomitic air } \\
\text { lime: silic. aggr. + } \\
\text { clay minerals }\end{array}$ & $1: 2$ & $\begin{array}{l}\text { Hyd. calcium } \\
\text { aluminate }\end{array}$ \\
\hline
\end{tabular}

Used notations: (-) - unidentified; (?) - uncertainty.

\subsubsection{XRD analysis}

Table 4 summarises the XRD composition of the mortars studied from Lisbon and Coimbra, respectively. The results show that the mortars are essentially of two types. The group of mortars from Lisbon is composed of calcitic air lime binder (containing mainly calcite) with siliceous aggregates. On the other hand, the group of mortars from Coimbra is composed of dolomitic air lime binder (containing calcite and hidromagnesite, as main binder markers), also with siliceous aggregates. The presence of dolomitic lime binder could be related to the use of local dolomitic limestone in the mortars formulation, given that this material is very typical in the region of Coimbra [25]. The presence of clay minerals, such as mica (illite) and kaolinite was detected in many of the analysed samples, with a higher incidence and relevance in Coimbra samples. This fact justifies the presence of hydrated calcium aluminates in most of Coimbra's mortars, as a result from the combination of the calcium $\left(\mathrm{Ca}^{2+}\right)$ and hydroxyl $\left(\mathrm{OH}^{-}\right)$ions constituent of lime with the alumina ions $\left(\mathrm{Al}^{3+}\right)$ released from clay particles, in an alkaline environment with a sufficient amount of water. The presence of clay minerals may be justified by the use of unwashed sands. The presence of gypsum and 
hydrocalumite was also observed in some cases. Gypsum presence may be due to different causes: internal and external. Internal causes may be related to some contamination with gypsum plaster or to an intentional addition in order to improve hardening time. External causes arise mainly from reaction of lime with sulphates from the external environment. Hydrocalumite could be the result of the reaction of lime with minerals from altered aggregates or from the use of materials with pozzolanic characteristics (such as calcined clay from brick powder).

\subsubsection{TG analysis}

The TG analysis confirmed the XRD results and allowed to quantify the binder content. Given the different mineralogical compositions of the samples of Lisbon and Coimbra, namely in terms of binder type (found through XRD analysis), the TG results from Lisbon and Coimbra samples were evaluated according to different temperature ranges, in order to obtain mass losses correspondent to the existent minerals.

In the Lisbon samples, the mass loss intervals established were the following:

$\mathrm{T}_{\mathrm{amb}}$ to $200{ }^{\circ} \mathrm{C}$, attributed to loss of moisture and crystallisation water (e.g. in samples containing gypsum); 200 to $500{ }^{\circ} \mathrm{C}$ - mainly associated to loss of water from hydrated compounds like clay minerals, such as kaolinite; 500 to $850{ }^{\circ} \mathrm{C}$ - attributed to loss of carbon dioxide due to decarbonation of calcium carbonate.

In Coimbra samples, the mass loss intervals established were the following (with appropriate adjustments): $\mathrm{T}_{\mathrm{amb}}$ to $200{ }^{\circ} \mathrm{C}$ - loss of moisture and crystallisation water; 200 to $380{ }^{\circ} \mathrm{C}$ - mainly due to the loss of water from the hydromagnesite decomposition; 380 to $450{ }^{\circ} \mathrm{C}$ - loss of carbon dioxide from the decomposition of magnesite; 450 to 540 ${ }^{\circ} \mathrm{C}$ - loss of water from the decomposition of clay minerals; 540 to $850{ }^{\circ} \mathrm{C}$ - loss of carbon dioxide due to decarbonation of calcium carbonate. 


\subsubsection{Chemical analysis}

The chemical analysis allowed to determine the content of insoluble residue in order to calculate the binder:aggregate ratios, based on the binder content value obtained by TG. The values obtained (mass ratios) are presented in Table 4, ranging between 1:1 (PL sample) to 1:11 (TAV1 and TAV3 samples) for Lisbon samples, and between 1:2 (MMC14, MMC17, MMC21 samples) to 1:6 (MMC2, MMC7, MMC20 samples) for Coimbra samples.

The differentiation of results obtained by type of building (Table 4) suggests the hypothesis that the professionals applying air lime mortars adapted the formulation to the type of building to be used in, probably by economic reasons, with special increase of the binder content in the azulejos setting mortars of religious and military buildings. This trend had also been found for other kinds of coating mortars reported in literature $[2,26]$. Concerning TAV1 sample, with the lowest binder:aggregate mass ratio, there may have been some removal of binder with time due to natural weathering. However, when the proportions binder: aggregate are presented in volume, considering probable loose bulk densities of the materials, the correspondent volumetric ratios are not so uncommon for current buildings. Additionally, when a part of clay is included in a mortar mix, the workability and cohesion improve and lime content may be reduced.

\subsubsection{SEM/EDS analysis}

SEM/EDS analysis (Figure 8) confirmed that the aggregates are of siliceous nature, presenting a large amount of quartz (identified with " 1 ") and feldspars (identified with “2”). Lime lumps (identified with “3”) were also visible in some cases. With this confirmation, it is safe to say that the carbonate content present in the samples comes only from the binder, allowing to state that the values of binder:aggregate ratio obtained have a high degree of confidence. 

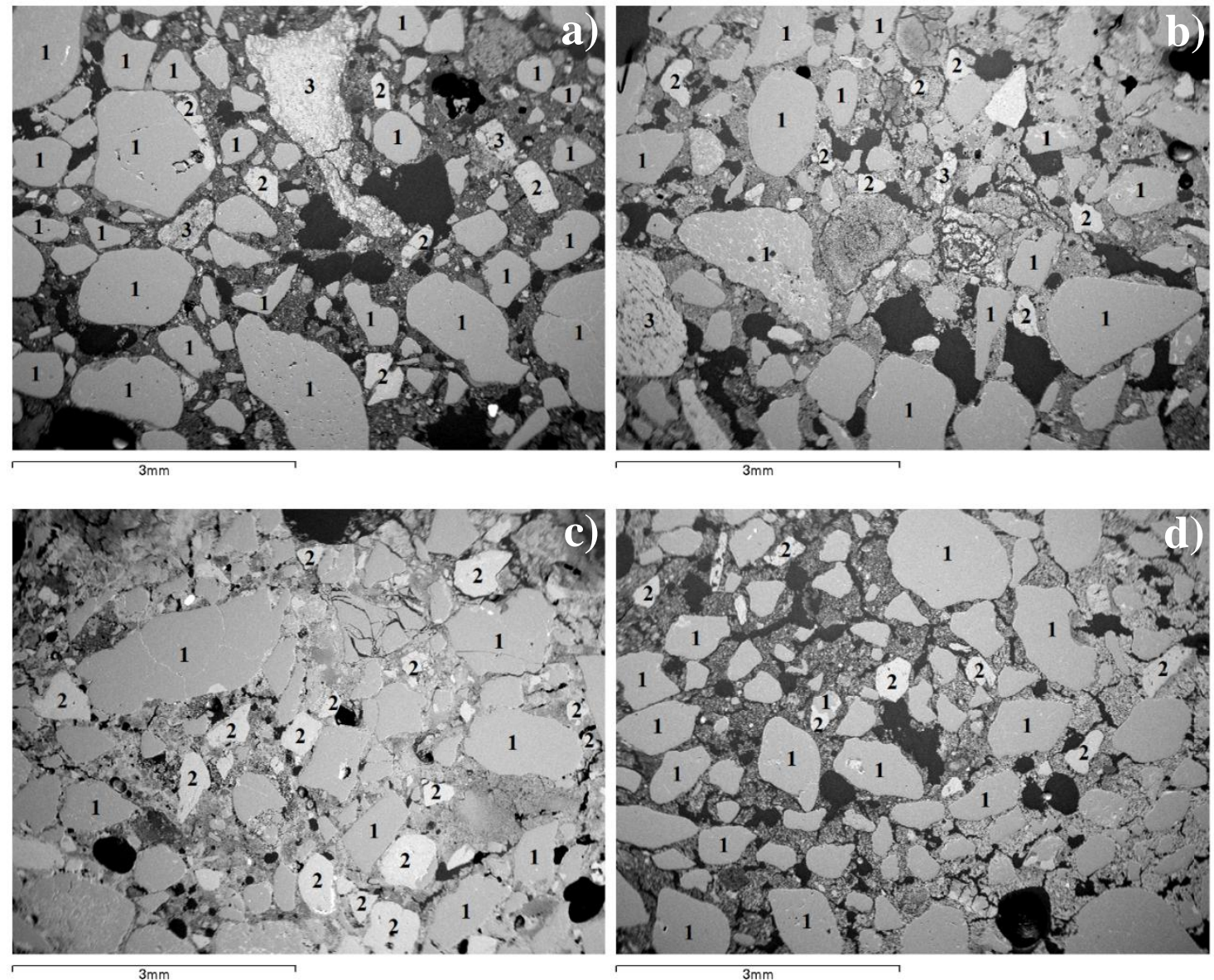

Figure 8 - SEM images of polished sections of samples TAV2 (a), TAV4 (b), HA1 (c) and IMD (d) showing the presence of silica (1) and feldspar (2) aggregate grains, and lime lumps (3) of the binder

This analysis confirms the XRD mineralogical composition, namely that quartz and feldspars are the main constituents of the aggregates in samples TAV2, TAV4 and HA1, while in the IMD sample the feldspar presence is only minor.

In addition, SEM enables to discriminate the porosity of the different samples, being TAV4 the more porous and HA1 the most compact. This fact complies with the results from Po test, which showed that TAV4 (29\%) is more porous than HA1 (26\%), and, as can be seen in the following section, is consistent with compressive strength results, where TAV4 presents a lower CS $\left(1.89 \mathrm{~N} / \mathrm{mm}^{2}\right)$ than HA1 $\left(3.34 \mathrm{~N} / \mathrm{mm}^{2}\right)$. 


\subsection{Physico-mechanical characterisation}

The mean results obtained from the physico-mechanical characterisation are summarised in Table 5. The samples are presented in chronological order, whenever the age of the building and/or the provenance of the azulejos are known. The main conclusions extracted from their analysis and correlations are presented in the following sections.

Table 5 - Results of physical and mechanical characterisation of azulejos setting mortars

\begin{tabular}{|c|c|c|c|c|c|c|}
\hline \multirow{2}{*}{$\begin{array}{l}\text { Case study/Age/ Type of } \\
\text { building }\end{array}$} & \multirow{2}{*}{ Sample } & \multirow{2}{*}{$\begin{array}{c}\mathrm{CS} \\
\mathrm{N} / \mathrm{mm}^{2}\end{array}$} & \multirow{2}{*}{$\begin{array}{c}\mathrm{D} 1 \\
\mathrm{~kg} /\left(\mathrm{m}^{2} \text {. }\right. \\
\min )\end{array}$} & D2 & Cec & \multirow{2}{*}{ Po \% } \\
\hline & & & & \multicolumn{2}{|c|}{$\begin{array}{l}\mathrm{kg} /\left(\mathrm{m}^{2} .\right. \\
\left.\min ^{1 / 2}\right)\end{array}$} & \\
\hline \multirow{4}{*}{$\begin{array}{l}\text { Building from Travessa } \\
\text { André Valente, } \mathrm{n}^{\circ} 13 \text {, } \\
\text { Lisbon } / 17^{\text {th }}-18^{\text {th }} / \text { Palatial }\end{array}$} & TAV1 & 0.62 & 0.0024 & 0.0674 & 2.91 & 28.5 \\
\hline & TAV2 & - & 0.0019 & 0.0508 & 0.27 & 26.0 \\
\hline & TAV3 & - & 0.0024 & 0.0674 & 2.59 & 29.0 \\
\hline & TAV4 & 1.89 & 0.0011 & 0.0443 & 1.50 & 29.0 \\
\hline $\begin{array}{c}\text { Chapel of Flamenga } \\
\text { Sanatorium, Vialonga, } \\
\text { Lisbon/17 } 17^{\text {th }} \\
18^{\text {th }} / \text { Religious/ }\end{array}$ & CAS & 1.63 & 0.0019 & 0.1015 & 1.69 & 36.0 \\
\hline $\begin{array}{c}\text { Arroios Hospital, } \\
\text { Lisbon } / 18^{\text {th }} / \text { Religious }\end{array}$ & HA1 & 3.34 & 0.0028 & 0.0796 & 2.54 & 26.0 \\
\hline $\begin{array}{l}\text { Church of Madre de } \\
\text { Deus Convent, } \\
\text { Lisbon/18 } / \text { Religious }\end{array}$ & IMD & - & 0.0022 & 0.0652 & 1.56 & 28.0 \\
\hline $\begin{array}{c}\text { Building from } \\
\text { Regimento dos } \\
\text { Lanceiros, Ajuda- } \\
\text { Belém, Lisbon } / 18^{\text {th }}- \\
19^{\text {th }} / \text { Palatial }\end{array}$ & RL1 & 2.68 & 0.0013 & 0.0685 & 1.03 & 23.5 \\
\hline
\end{tabular}


Used notation: CS - compressive strength; Ccc - capillary absorption coefficient; D1 - first drying phase rate; D2 - second drying phase rate; $\mathrm{Po}$ - open porosity; (-) - unidentified

Complementary data: Dynamic modulus of elasticity by ultrasounds of sample TAV4 is 3674 $\pm 437 \mathrm{~N} / \mathrm{mm}^{2}$.

\subsubsection{Compressive strength}

The compressive strength test, as previously mentioned, was only performed on 5 specimens, due to size limitations, and the results obtained are summarised in Table 5. As can be seen, HA1 is the specimen with the highest CS $\left(3.34 \mathrm{~N} / \mathrm{mm}^{2}\right)$ and TAV1 presented the lowest $\left(0.62 \mathrm{~N} / \mathrm{mm}^{2}\right)$. In general, mortars with lower binder content correspond to lower CS values.

\subsubsection{Capillary absorption and drying of the absorbed water}

Since old lime based mortars have currently a high proportion of large pores [27], and because the samples are very thin (approximately 1-1.5 $\mathrm{cm}$ ) leading to quick saturation of these pores, the highest water absorption occurs in the first few minutes. Therefore, the range of points to be considered in the calculation of Ccc was adjusted case by case in order to perform the determination in the straight part of the graphic: the more significant capillary absorption stage. The capillary absorption results are presented in Table 5 and Figure 9 shows the absorption curves of all samples during the first 90 minutes $\left(9.49 \mathrm{~min}^{1 / 2}\right)$. Figure 10 shows some examples of determination of capillary coefficient. TAV2 was clearly the sample with the lowest Ccc value $(0.27$ $\left.\mathrm{kg} /\left(\mathrm{m}^{2} \cdot \mathrm{min}^{1 / 2}\right)\right)$. Considering the low binder:aggregate weight ratio of this sample, this Ccc value may be due to the possible presence of some product/treatment with water repellent effect applied for repair of the azulejos, that can slow down the capillary absorption. The use of a more compact setting mortar in an intervention of that area of the azulejo panel is another possibility. The presence of clay minerals, detected in this sample, may also reduce water absorption. 


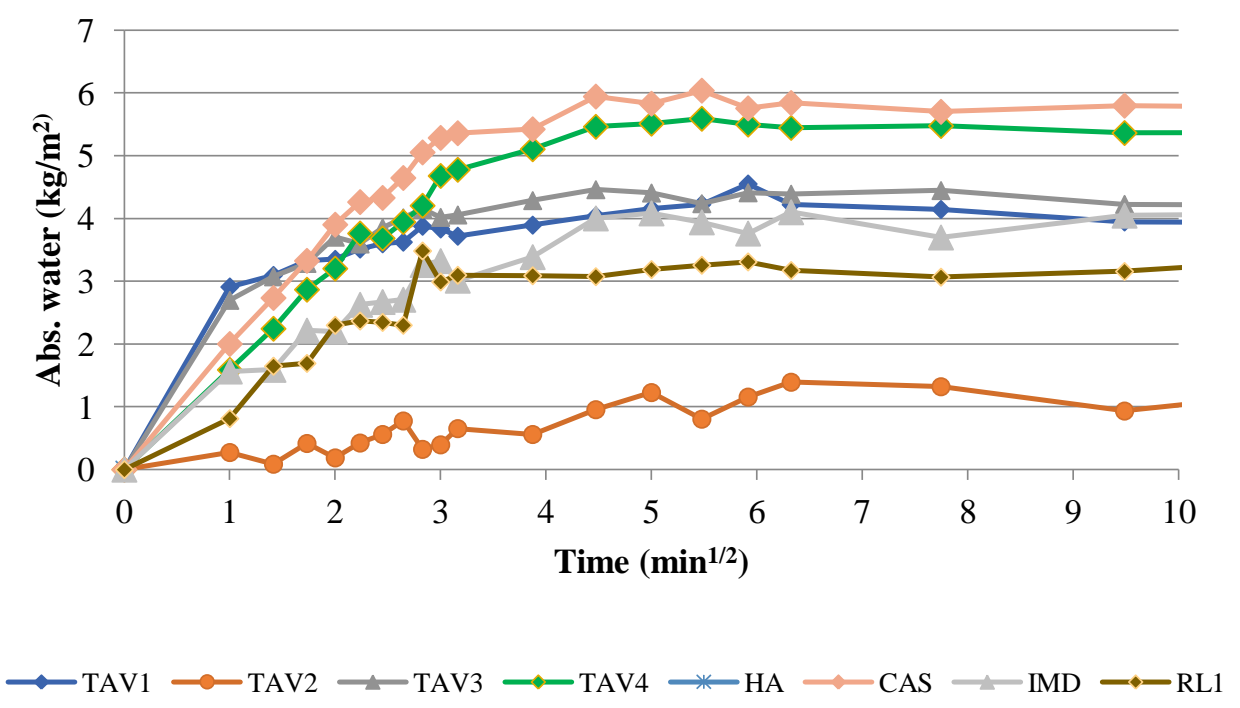

Figure 9 - Capillary absorption curves during the first $90 \mathrm{~min}\left(9.49 \mathrm{~min}^{1 / 2}\right)$

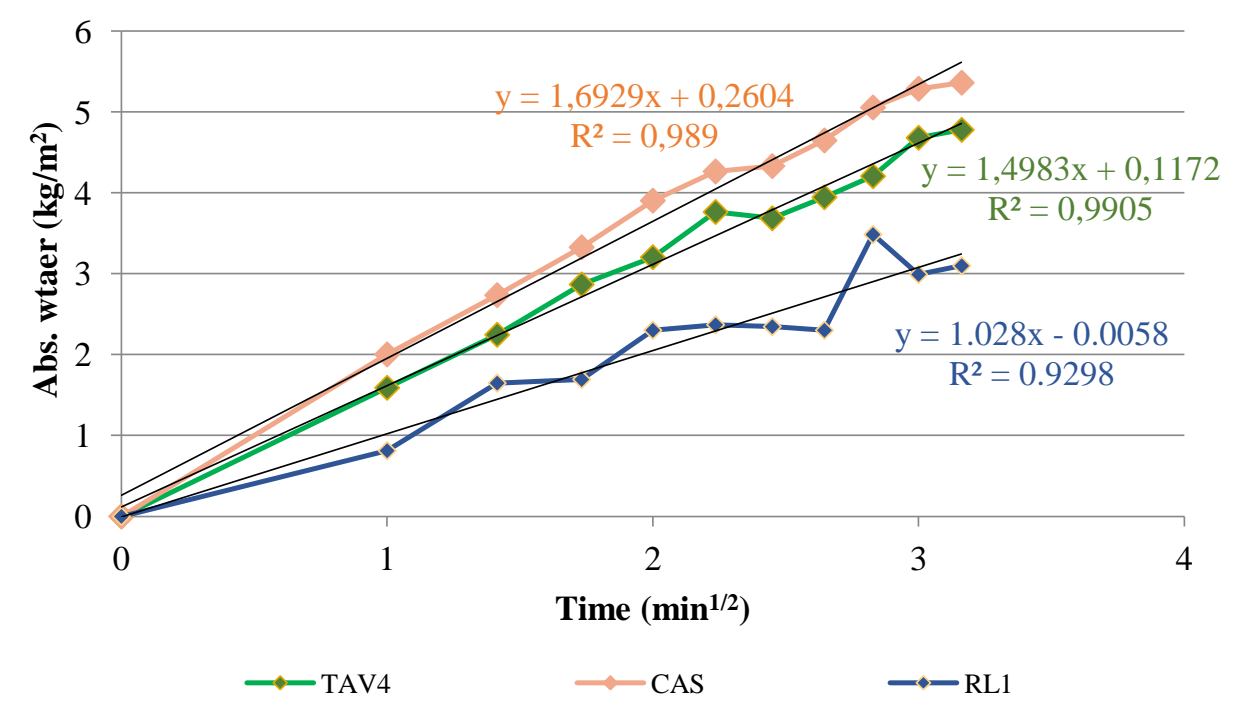

Figure 10 - Examples of calculation of capillary coefficients as the slope of the trendline for the linear part of the graphic

Drying rates are presented in Table 5. In Figure 11 it can be verified that samples TAV1 and IMD show simultaneously high D1 and relatively high D2, indicating high transport of liquid water to the surface of the sample, followed also by high evaporation, which are consistent with their high Ccc and medium porosity, possibly with predominance of macropores. On the contrary, CAS and RL1 present lower D1 and higher D2, i.e., lower 
liquid water transport to the surface but higher diffusion of water vapour, which may indicate a predominance of small pores that slow down the first phase of evaporation.

Figure 12 indicates a general trend of increase of D1 $\left(\mathrm{kg} /\left(\mathrm{m}^{2} \cdot \mathrm{min}\right)\right.$ with Ccc $\left(\mathrm{kg} /\left(\mathrm{m}^{2} \cdot \mathrm{min}^{1 / 2}\right)\right.$, even if the correlation is poor. In this correlation TAV2 was not considered, as it has already been concluded that its Ccc is probably affected by a treatment product.

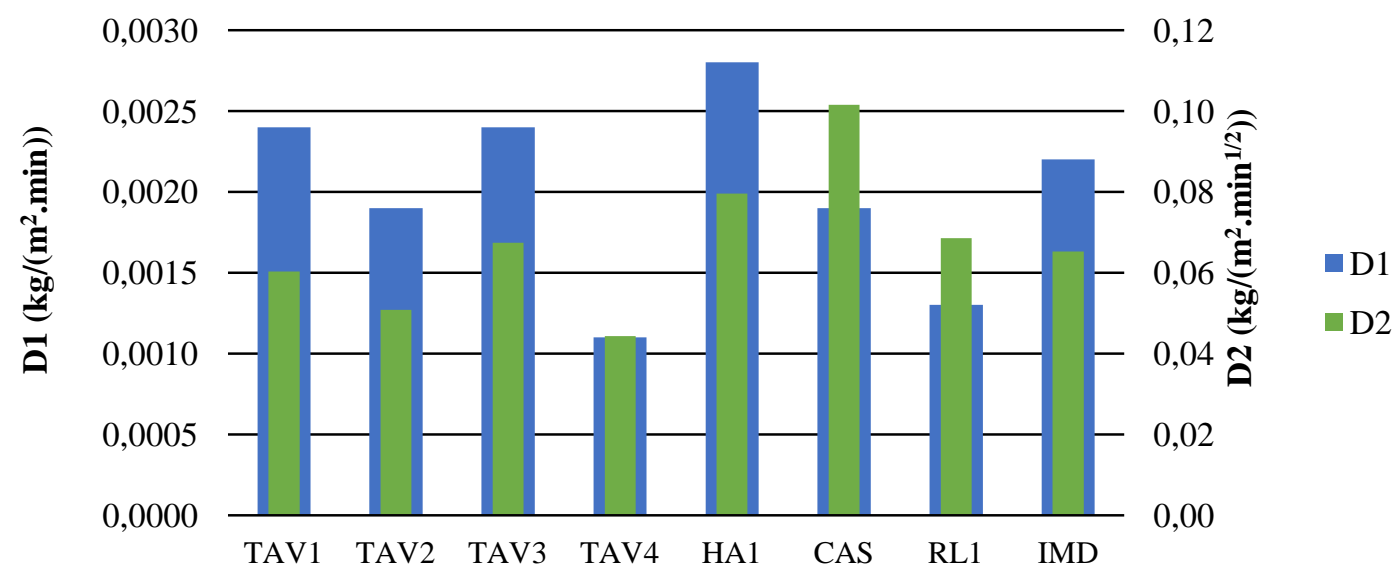

Figure 11 - Comparison between the two main drying phases (D1 and D2)

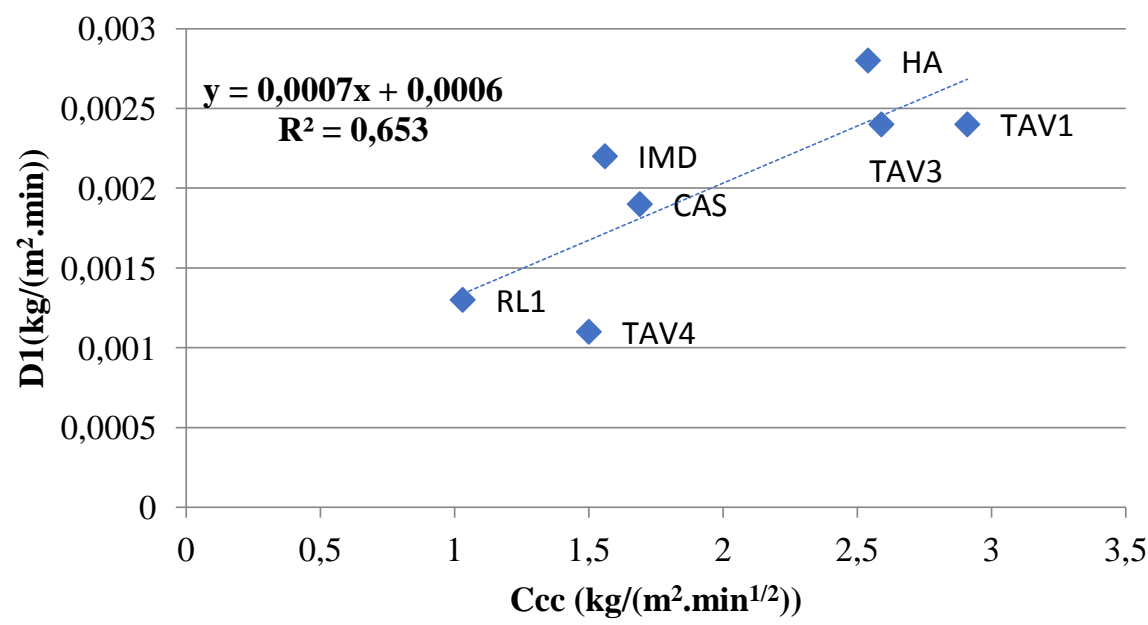

Figure 12 - Correlation between the first drying phase (D1) and capillary absorption $(\mathrm{Ccc})$ 
Generally, high Ccc are related with a high volume of large capillaries (>0.05 micron [28]) and lower Ccc, for the same porosity, corresponds to a predominance of smaller pores $[29,30]$, which in the case of air lime mortars would be mainly in the medium capillary pores range (10 to $50 \mathrm{~nm})$ [28]. The significant correlation between D1 and Ccc confirms that also D1 is related with a high volume of large capillaries.

\subsubsection{Open porosity}

Open porosity $(\mathrm{Po})$ results are summarised in Table 5. The sample with the highest Po is CAS (36\%), in agreement with the higher friability of this sample when compared to the others, in the initial analysis (Table 2). The lowest value was registered for RL1 (23.5\%), which complies with its good cohesion (Table 2), high CS (2.68 N/mm²), low

Ccc $\left(1.03 \mathrm{~kg} /\left(\mathrm{m}^{2} \cdot \mathrm{min}^{1 / 2}\right)\right)$ and correlated low D1 $\left(0.0013 \mathrm{~kg} /\left(\mathrm{m}^{2} \cdot \mathrm{min}\right)\right.$, indicating predominance of medium capillary pores. This value is also consistent with high binder content $(1: 2$, as shown in Table 4).

Figure 13 presents the correlation between open porosity and compressive strength, excluding the sample CAS whose abnormally high porosity seems to indicate a high deterioration degree. Although the correlation is poor (low $\mathrm{R}^{2}$ of 0.44 ), due to the influence of other factors in compressive strength (such as the nature of aggregate) in general, it can be verified that samples with lower CS present higher Po. In addition, Tables 4 and 5 show that the samples with highest CS and lowest Po are also the ones with highest binder: aggregate ratios. 


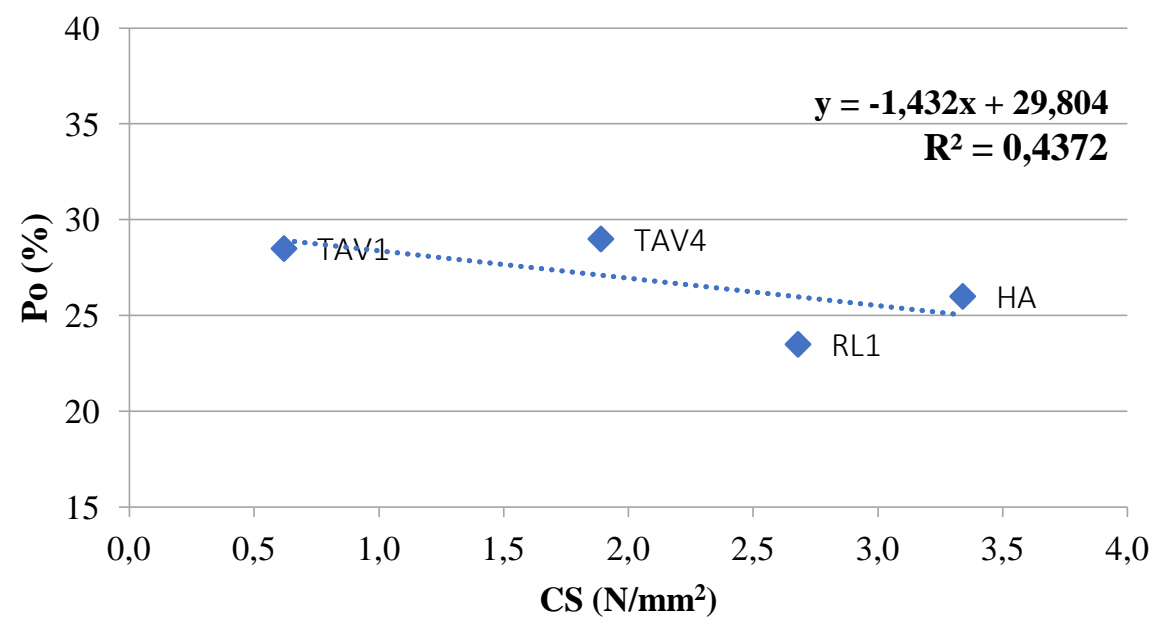

Figure 8 - Correlation between open porosity and compressive strength

\subsection{Global analysis of the results}

\subsubsection{Variability within each building}

An analysis of variability within each case study can only be done for the few cases from which several specimens could be analysed: ARQ 1-4; HM 1-2; TAV 1-4; HA 13; MMC 1-21 (with the reserve that they may or not be from different buildings); RL 1-

2.

Each one of the referred samples, with few exceptions, showed homogeneity of composition, with similar constituents and narrow ranges of binder:aggregate ratios. The main exception is TAV 1-4, with binder:aggregate ratios variable between 1:5 and 1:11. However, TAV samples are from different panels, although they belong to the same building. Also MMC 1-21 show binder:aggregate ratios variable between 1:2 and $1: 6$, but it is not assured that they belong to the same building.

For the other four cases: samples ARQ 1-4, from Lisbon, $16^{\text {th }}$ cent., are all composed by calcitic air lime, silicious aggregate and clay minerals, with proportions 1:2 or 1:3 except for ARQ 1 which has a much lower binder proportion, possibly due to weathering and consequent loss of binder; sample HM 1-2, from Lisbon, $17^{\text {th }}$ cent., 
have similar constituents and also binder:aggreg. ratios 1:2; HA 1-3, Lisbon, $18^{\text {th }}$ cent., have again the same main constituents but medium binder contents, of 1:3 and 1:4; and RL $1-2$, Lisbon $18^{\text {th }}-19^{\text {th }}$ cent. are composed by calcitic air lime and siliceous aggregate in the proportion 1:2. The sample HA 1-3, in spite of medium binder:aggregate ratio, shows rather high compressive strength but also high capillarity: nevertheless, only one specimen was submitted to physical-mechanical tests. On the other hand, RL1-2 samples present relatively high compressive strength, low capillary coefficient and porosity; again, only one specimen was submitted to physical-mechanical tests.

Concerning TAV 1-4 samples, composed by calcitic air lime:silicious aggregate + clay minerals, have the lowest and most disperse binder:aggregate ratios, which may indicate lower quality of workmanship and possibly of materials, that may explain variation during construction or degradation, and probably also loss of binder due to weathering. Degradation products found (gypsum and hydrocalumite) are other indications of this last hypothesis of higher degradation level. Together with composition dispersion, a significant dispersion of physical-mechanical properties was found. A trend is visible of lower binder proportion corresponding to lower mechanical strength and higher hygric indicators Ccc (with the already referred exception of TAV2), D1 and D2.

As for MMC 1-21, all the samples are from Coimbra, probably $18^{\text {th }}$ cent. - but this dating is not certain - and they are all composed by dolomitic air lime:silicious aggregate + clay minerals, showing also all of them traces of hydrated calcium aluminate. However, the binder:aggregate ratio is variable. This dispersion may be due to original construction differences, as there is no confirmation that they are from the same building, or it may also be a result of degradation, or at least alteration reactions along their life cycle.

\subsubsection{Comparison of samples characteristics of the different case studies}


A comparison between the different case studies immediately shows a significant difference between the mortars from Lisbon and from Coimbra: while the binder of Lisbon mortars is in all cases calcitic air lime, Coimbra mortars have dolomitic mortar as a binder in their composition. This difference is explained by the different geologic resources in the two regions and is in line with previous studies of other mortars in both regions $[2,25,26]$.

Considering Lisbon mortars, it is visible that the samples from military and from religious buildings have the highest binder:aggregate ratios (respectively 1:2 and 1:3) and a public building (hospital) shows medium binder contents (1:3, 1:4) while residential buildings evidence the lowest binder contents. These differences may be attributed to the importance given to the several kinds of buildings, reflected on the materials used, as has already been identified in previous studies of Portuguese old mortars $[2,26]$.

Setting mortars of azulejos panels are less exposed in comparison with other coating mortars because of the protection provided by the azulejos. Nevertheless migration of water may exist by the joints and, during all the life span of an azulejos panel, the setting mortar may have been exposed for some periods, namely during repair interventions. Hence, even considering the protection of the azulejos, for the mortars with the lowest lime contents, which could be initially less cohesive, the processes of degradation and consequent loss of binder may have reduced the present ratio binder:aggregate.

\subsubsection{Comparison of characteristics with other coating mortars}

The comparison of azulejos setting mortars with other air lime coating mortars of the same period shows that the binder:aggregate ratios obtained for the setting mortars of this set of case studies (with the exception of TAV samples) - 1:1 to 1:4 - are in the 
same range as those determined for lime coating mortars of previously studied Portuguese military and religious buildings [26] - respectively $1: 1.5$ to $1: 3$ and $1: 1.5$ to 1:4.5. Consistently, the ranges of compressive strength -1.63 to $3.34 \mathrm{kN} / \mathrm{mm}^{2}-$ are within the range of the referred buildings -2.0 to $7.0 \mathrm{kN} / \mathrm{mm}^{2}$ and 2.3 to $3.5 \mathrm{kN} / \mathrm{mm}^{2}$, respectively. Finally, concerning coefficients of capillarity, the values determined -1.03 to $2.54 \mathrm{~kg} /\left(\mathrm{m}^{2} \cdot \mathrm{min}^{1 / 2}\right)$ - are also in accordance with those found previously for coating mortars of military Portuguese old buildings -0.2 to $6.2 \mathrm{~kg} /\left(\mathrm{m}^{2} \cdot \mathrm{min}^{1 / 2}\right)$. However, in the previously studied religious buildings the range for capillary coefficients was lower 0.11 to $1.2 \mathrm{~kg} /\left(\mathrm{m}^{2} \cdot \mathrm{min}^{1 / 2}\right)$ respectively.

Concerning TAV values, they are within the large ranges found for residential buildings $[2,26]$, which show in general higher variability and lower characteristics than the buildings intended for so considered nobler uses.

\section{CONCLUSIONS}

A set of samples of old azulejos setting mortars from the Portuguese towns of Lisbon and Coimbra, of $16^{\text {th }}$ to $19^{\text {th }}$ centuries, was studied. All the mortars showed to be composed by air lime and siliceous aggregates, usually with addition of clay. The results showed a clear difference between azulejos setting mortars from Lisbon and those from Coimbra. Lisbon mortars have a calcitic air lime binder, with siliceous aggregates and traces of clay minerals. On the other hand, Coimbra mortars have a dolomitic air lime binder, with siliceous aggregates and in most cases a significant amount of clay minerals. In Lisbon mortars the binder:aggregate weight ratios found were mostly between 1:2 and 1:4, with the exception of one sample with $1: 1$ and of residential buildings which had lower binder content. For Coimbra, the proportions were between 1:2 and 1:6. The physical characteristics could only be measured for some samples, all of them from Lisbon mortars, due to the small sizes of the fragments of the 
other samples which did not allow carrying out those tests with reasonable accuracy. This study should then be continued, whenever samples are available, with more testing of physical characteristics, especially for Coimbra mortars. Concerning the samples that could be tested, it was verified that the compressive strength values -1.63 to 3.34 $\mathrm{kN} / \mathrm{mm}^{2}$ with the exception of TAV1 - and the capillary coefficient values -1.03 to $2.54 \mathrm{~kg} /\left(\mathrm{m}^{2} \cdot \mathrm{min}^{1 / 2}\right)$ with the exception of TAV2 - are within the ranges found in the literature for old air lime coating mortars of public buildings $[2,17,26]$.

Comparing the results obtained in this study with the ones gathered from the literature also allows to assess the results of azulejos setting mortars used indoors and in the facade of buildings. Several similarities (especially with respect to binder:aggregate ratio) were verified, leading to the idea that no special distinction was made in the formulation of this type of mortars for the interior or exterior. In order to confirm this hypothesis, it is important and pertinent to carry out tests on these two groups of mortars, from the same building, so that other influencing factors, such as different construction period, region or type of building, do not interfere in the conclusions.

Finally, it was found that these mortars did not follow a chronological pattern, but they differ from region to region, certainly due to the use of local materials in the mortars formulation, and also to the experience of the applicators. Moreover, the differentiation of the results obtained by the type of building leads to believe that the professionals preparing air lime coating mortars adapted the formulation to the type of building to be used in and the resources available, with special increase of the binder content in the azulejos setting mortars of military and religious buildings and then for other public buildings, such as hospitals. This trend had also been found for other kinds of coating mortars reported in literature.

\section{ACKNOWLEDGEMENTS}


All the experimental work was carried at the National Laboratory for Civil Engineering (LNEC), Buildings Department and Materials Department for physico-mechanical and chemical-mineralogical characterisations, respectively. The authors wish to thank to Museu Nacional do Azulejo for providing all the old azulejos' setting mortars used in this study and also to Fundação para a Ciência e Tecnologia (Portuguese Foundation for Science and Technology) for the financial contribution within research project PTDC/EPH-PAT/4684/2014: DB-HERITAGE (Database of building materials with historical and heritage interest).

\section{REFERENCES}

[1] Veiga M. R., Fragata A., Velosa A. L., Magalhães A. C., Margalha M. G. Limebased mortars: viability for use as substitution renders in historical buildings. Int. J. Archit. Heritage 2010; 4 (2): 177-195, doi: 10.1080/15583050902914678.

[2] Damas, A. L., Veiga, M. R., Faria, P. Characterisation of old mortars of Portugal contribution to its correct conservation (in Portuguese). In: Congresso Ibero-Americano “Património, suas Matérias e Imatérias”. LNEC, Lisbon, Portugal; 2016.

[3] Candeias, A. E., Nogueira, P., Mirão, J., Silva, A. S., Veiga, R., Casal, M. G., Ribeiro, I., Seruya, A.I. Characterisation of ancient mortars: present methodology and future perspectives. In: Workshop on Chemistry in the Conservation of Cultural Heritage: present and future perspectives. Perugia, Italy; 2006.

[4] Botas, S., Veiga, M. R., Velosa, A. L. Air lime mortars for conservation of historic tiles: Bond strength of new mortars to old tiles. Constr. Build. Mater. 2017; 145:426434, http://dx.doi.org/10.1016/j.conbuildmat.2017.04.027. 
[5] Velosa, A. L.; Coroado, J.; Rocha, F. Characterisation of stone and mortar decay Casa Major Pessoa, Aveiro. In: HWC 2006, International Conference on Heritage, Weathering and Conservation, Madrid, Spain; 2006.

[6] Teixeira, B., Valente, C., Velosa, A. L., Veiga, M. R., Ferreira, I. M. Development of lime based mortars for repairing glazed tiles coating of historic buildings in the city of Ovar, Portugal. In: HMC08, 1st Historical Mortars Conference, LNEC, Lisbon, Portugal; 2008.

[7] Ferreira, M. I. M. Traditional facade tiles in Ovar. Contributions to a conservation and restoration methodology (in Portuguese). Câmara municipal de Ovar / ACRA Atelier de Conservação e Restauro do Azulejo; 2009.

[8] Coroado, J., Paiva, H., Velosa, A., Ferreira, V. M. Characterisation of renders, joint mortars and adobes from traditional constructions in Aveiro (Portugal). Int. J. Archit. Heritage 2010; 4:102-114, doi:10.1080/15583050903121877.

[9] Japiassú, P. Study of the adhesion mechanism of lime tiles and mortars in historic coatings (in Portuguese). MSc thesis, Goias Federal University, Goiânia, Brazil; 2011.

[10] Andrejkovičová, S., Pires, D., Ferreira, L.M., Velosa, A. L.; Rocha, F., Labrincha, J. Chemical and mechanical characterisation of Ovar mortars (in Portuguese). In: Congresso Internacional Azulejar - Conservação de Revestimentos Azulejares em Fachadas. Aveiro University, Portugal; 2012, p.1-11.

[11] Japiassú, P., Carasek, H., Cascudo, O., Velosa, A. L., Oliveira, M. C. B., Chotoli, F. F., Quarcioni, V. A. Characterisation of the tile/mortar interface of historical façades (in Portuguese). ALCONPAT 2014; 4(1):52-73, doi: 10.21041/ra.v4i1.61. 
[12] Carasek, H., Japiassú, P., Cascudo, O., Velosa, A. Bond between 19th Century lime mortars and glazed ceramic tiles. Constr. Build. Mater. 2014; 59:85-98, http://dx.doi.org/10.1016/j.conbuildmat.2014.02.043.

[13] Mendes, M. T. Conservation and restauration of glazed tiles. A study of setting mortars (in Portuguese). MSc thesis, Lisbon University; 2008.

[14] Mendes, M. T., Antunes, J. L. F., Coroado, J. Conservation and restoration of glazed tiles. A study of setting mortars. In: HMC08, 1st Historical Mortars Conference, LNEC, Lisbon, Portugal; 2008.

[15] Mariz Ferreira, L. El azulejo de la arquitectura de Oporto (1850-1920), PhD thesis, Facultad de Bellas Artes, Basque Country University; 2009.

[16] CEN. EN 1015-11:1999/A1:2006 - Methods of test for mortar for masonry. Part 11: Determination of flexural and compressive strength of hardened mortar. Brussels, CEN ; 1999.

[17] Magalhães, A, Veiga, M. R. Physical and mechanical characterisation of ancient mortars. Application to the evaluation of the state of conservation. Mater. Construcc. 2009; 59(295): 61-77, doi: 10.3989/mc.2009.41907.

[18] Válek, J., Veiga, M. R. Characterisation of mechanical properties of historic mortars - Testing of irregular samples. Adv. Arc. Ser. 2005; 20: 365-374, doi: 10.2495/STR050351.

[19] CEN. EN 14146:2004 - Natural stone test methods - Determination of the dynamic modulus of elasticity (by measuring the fundamental resonance frequency). Brussels, CEN; 2004. 
[20] CEN. EN 15801:2009 - Conservation of cultural property - Test methods Determination of water absorption by capillarity. Brussels, CEN; 2009.

[21] Veiga, M. R., Magalhães, A. C., Bokan-Bosilikov, V. Capillarity tests on historic mortar samples extracted from site. Methodology and compared results. In: $13^{\text {th }}$ International Brick and Block Masonry Conference, Amsterdam, Netherlands; 2004.

[22] CEN. EN 16322:2013 - Conservation of cultural heritage- Test, methods Determination of drying properties. Brussels, CEN; 2013.

[23] CEN. EN 1936:2006 - Natural stone test methods - Determination of real density and apparent density, and of total and open porosity. Brussels, CEN; 2006.

[24] Silva, A. S., Adriano, P., Magalhães, A., Pires, J., Carvalho, A., Cruz, A. J., Mirão, J., Candeias, A. Characterisation of historical mortars from Alentejo's religious buildings. Int. J. Archit. Heritage 2010a; 4(2):138-154, doi: $10.1080 / 15583050903046322$

[25] Providência, P., Tavares, M., Catarino, L., Silva, A. S. Historic Centre of Coimbra: Characterisation of coating mortars (in Potuguese). In: $4^{o}$ Congresso Português de Argamassas e ETICS., Coimbra, Portugal; 2012.

[26] Velosa, A. L., Veiga, M. R. Historical heritage mortars: knowledge to preserve and refurbish (in Portuguese). In: CINPAR - XII Congresso Internacional sobre Patologia e Reabilitação de Estruturas. Porto, Portugal; 2016.

[27] Lanas, J., Alvarez, J.I. Masonry repair lime-based mortars: Factors affecting the mechanical behavior. Cem. Concr. Res. 2003; 33:1867-1876, doi: 10.1016/S00088846(03)00210-2 
[28] Pipilikaki, P., Beazi-Katsioti, M. The assessment of porosity and pore size distribution of limestone Portland cement pastes. Const. Build. Mater. 2009; 23 (5):1966-1970, doi: 10.1016/j.conbuildmat.2008.08.028.

[29] Meng, B. Resolution-dependent characterization of interconnected pore systems: development and suitability of a new method. Mater. Struct. 1994; 27(2):63-70, doi:10.1007/BF02472823.

[30] Arandigoyen, M., Alvarez, J. I. Blended pastes of cement and lime: pore structure and capillary porosity. Appl. Surf. Sci. 2006; 252:8077-8085, doi: 10.1016/j.apsusc.2005.10.019r. 